\title{
Comparison of Chemical Treatment Methods for Loblolly Pine to Utilize as Enzyme Hydrolyzate Feedstock ${ }^{\#}$
}

\author{
Arpan Jain ${ }^{1 \S}$, William C Bridges ${ }^{2}$, Karl Kelly ${ }^{3}$ \\ Biosystems Engineering Program, Department of Environmental Engineering and Earth \\ Sciences, Clemson University, SC, $29634^{1}$ \\ Department of Mathematical Sciences, Clemson University, SC, $29634^{2}$ \\ Center for Human Genetics, Clemson University, SC, $29646^{3}$
}

\#Work performed under this manuscript has been filled for US patent application WO 2013151927 A1, "Pretreatment composition for biomass conversion process". Filing date April 2013.

${ }^{\S}$ Corresponding author

Author

Arpan Jain, $\mathrm{PhD}^{\S}$

Biosystems Engineer

Email: arpanjain0211@gmail.com; arpanj@g.clemson.edu

Phone: +1 8643092320

Present Postal Address: 1507 South $4^{\text {th }}$ Street, Apt\#2, Louisville, KY, 40208, USA.

Permanent Postal Address: Laxmi Bhawan, Sadar Bazar, Sirohi, Rajasthan, 307001, India

Co-Authors

William C Bridges, $\mathrm{PhD}$

Email: wbrdgs@clemson.edu

Karl Kelly

Email: karl@clemson.edu 
Abstract

The ground pine wood chips (GPWC) were examined through chemical treatment methods employing alkaline hydrogen peroxide treatment (AHP, consisted of $50 \mathrm{~g} \mathrm{~L}^{-1}$ potassium hydroxide, and $50 \mathrm{~g} \mathrm{~L}^{-1}$ hydrogen peroxide with added water at $78{ }^{\circ} \mathrm{C}$ for 24 h), and ethyl-hydro-oxides treatment (EHOs, consisted of $60 \%$ ethanol (of total solution), $50 \mathrm{~g} \mathrm{~L}^{-1}$ potassium hydroxide, and $50 \mathrm{~g} \mathrm{~L}^{-1}$ hydrogen peroxide with added water at $78{ }^{\circ} \mathrm{C}$ for $24 \mathrm{~h}$ ). The effects of chemical treatments on GPWC were examined through combination of chemical composition followed by enzymatic hydrolysis (using Accellerase ${ }^{\circledR}$ 1500). The application of EHOs treatment removes the foaming issue that currently occurs due to AHP treatment at the elevated temperature. A removal of the foaming phenomenon increased the enzymatic glucan conversion (>70\%) which is important in increasing the efficiency of biorefinery. The interaction of different variables in EHOs solvent formulations including ethanol concentration (0-60\%), potassium hydroxide concentration $\left(0-50 \mathrm{~g} \mathrm{~L}^{-1}\right)$, hydrogen peroxide concentration $\left(0-50 \mathrm{~g} \mathrm{~L}^{-1}\right)$, and processing temperature $\left(38^{\circ}-78{ }^{\circ} \mathrm{C}\right)$ were analyzed through four variables response surface methodology using glucan conversion and total polysaccharide conversion as responses. The glucan conversion and total polysaccharide conversion were analyzed to determine the specific and overall effects of Accellerase ${ }^{\circledR} 1500$ on the amorphous polysaccharide contents of GPWC resulted through EHOs treatment formulations, respectively. The implications of all these findings are discussed with the available literature.

\title{
Keywords
}

Pine wood chips; alkaline hydrogen peroxide (AHP) treatment; ethyl-hydro-oxides (EHOs) treatment; enzymatic saccharification; Accellerase ${ }^{\circledR} 1500$; four variable response surface methodology.

\begin{abstract}
Abbreviations
GPWC: Ground pine wood chips AHP: Alkaline hydrogen peroxide EHOs: Ethyl-hydro-oxides

\section{Introduction}

Softwood such as loblolly pine (Pinus taeda) is a fast-growing tree. Loblolly pine can reach a height of $18-30 \mathrm{~m}$ with a diameter of 0.3 to $1.5 \mathrm{~m}$ between $30-60$ years. Softwoods such as pine and spruce consist of 42-45 $\mathrm{g}$ of cellulose, 17-22 $\mathrm{g}$ of hemicellulose, and 24-32 $\mathrm{g}$ of lignin per $100 \mathrm{~g}$ of biomass (dry basis) [1-6]. The high polysaccharides content of loblolly pine (approx. $63 \mathrm{~g}$ per $100 \mathrm{~g}$ of dried biomass) is crucial for increasing both transportation and development of bio-product efficiencies. The conversion of pine wood chips into bio-products is an energy intensive process due to a tight binding of polysaccharides matrix with lignin content. To enhance the release of polysaccharide contents of softwood, both physical and thermochemical treatments are required. A physical treatment involves the size reduction of particles, thereby increasing the surface area per unit volume. Pine wood chips require 1.7-3.8 times more energy compared to corn stover for the same size reduction [7]. The milling energy of pine wood chips increases with the decreasing particle sizes [7,8]. Whereas, thermochemical treatments are required to convert crystalline content to amorphous content with removal of lignin. Several different thermochemical treatments employing steam [2], sulfuric acid
\end{abstract}


based reagents (such as Kraft [4], organosolv [3, 9,10], and alkaline sulfite-

anthraquinone-methanol (ASAM) [4]), alkaline hydroxide [5], and alkaline hydrogen peroxide (AHP) [6] have been reported for softwood conversion. The effects of thermochemical treatments on structural-chemical properties of softwoods can be measured through X-ray diffraction, scattering electron microscopy, kappa number, and enzyme digestibility [2-6].

Water is the most polar solvent and form hydrogen bonding with cellulosic hydroxyl groups on interaction. However, the hydrophobic nature of lignin inhibits water molecule interaction with cellulose. To overcome the physical barrier of lignin in softwood conversion, steam treatment is utilized at a high temperature of $180^{\circ} \mathrm{C}$ for $20 \mathrm{~min}$ [2]. Steam treatment at high temperature penetrates lignocellulosic biomass through formation of a hydronium ion [2]. The steam treatment promotes hemicellulose degradation and transforms lignin, thereby increasing access to cellulose content [2]. The application of steam treatment on softwood (particle size: $0.25-0.42 \mathrm{~mm}$ ) completely removes xylan content and decreases $22.5 \%$ of phenolic compounds without affecting its cellulose content [2]. During enzyme hydrolysis, steam treated softwood converts up to $4 \%$ and $12.5 \%$ of total polysaccharide into fermentable sugars at substrate loadings of 50 $\mathrm{g} \mathrm{L}^{-1}$ and $200 \mathrm{~g} \mathrm{~L}^{-1}$, respectively [2]. Sulfuric acid based reactants along with anthraquinone, organic solvents (such as ethanol and methanol) and alkaline hydroxide have been used with water to enhance softwood conversion [3-4, 9]. The paper pulp industry utilizes sulfuric acid based reactants on softwood (size: particle (less than $5 \mathrm{~mm}$ )

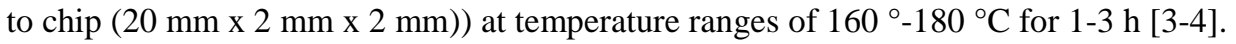
Compared to the conventional Kraft treatment, a significant improvement in both pulp brightness and yield have been reported with the application of ASAM treatment [4]. However, the use of carcinogenic anthraquinone in ASAM treatment formulation set back the process and its usage at commercial scale production [11]. Organic solvents (such as ethanol and methanol) are effective in the delignification of lignocellulosic biomass. Mantanis [12] has reported that the activation energy of softwood swelling (using spruce and Douglas-fir) ranges from 32.2- 38.9.0 KJ mol-1 and 57.1- $60.4 \mathrm{KJ} \mathrm{mol}^{-1}$ at the temperature of $23^{\circ}-100{ }^{\circ} \mathrm{C}$ using water and ethanol as solvents, respectively. The addition of $-\mathrm{CH}_{3}$ group causes a subsequent increase in the activation energy of wood using ethanol compared to water [12]. The maximum swelling of wood in the aqueous organic solvent is accompanied by solvent basicity, molar volume, and hydrogen bonding capability [12]. In organosolv treatment, use of ethanol (50-80\% of solution) along with mineral catalysts such as $\mathrm{H}_{2} \mathrm{SO}_{4}$ (1.0-1.1 g per g of biomass) at elevated temperature (160 ${ }^{\circ}-200{ }^{\circ} \mathrm{C}$ ) increases both delignification and enzymatic saccharification of softwood [10]. The application of organosolv treatment $\left(65 \%\right.$ ethanol of total solution and $1.1 \mathrm{~g} \mathrm{H}_{2} \mathrm{SO}_{4}$ per g of biomass; processing temperature $=170{ }^{\circ} \mathrm{C}$ for $1 \mathrm{~h}$ ) on softwood (particle size: less than $5 \mathrm{~mm}$ ) removes $61.2 \%$ of phenolic compounds with $79 \%$ of glucose recovery, and increases enzymatic glucan conversion up to 70\% [3]. Organosolv treatment involves the formation of hydro ion $\left[\mathrm{H}_{3} \mathrm{O}^{+}\right]$similar to the acid treatment [10]. The generated lignin through organosolv treatment has a potential market value in the development of carbon fibers $[10,13]$. The use of organosolv treatment is limited in the biofuel industry due to a high price of solvent, high temperature processing, and an expensive infrastructure development. Moreover, the processing temperature at above $170{ }^{\circ} \mathrm{C}$ produces furfural and hydroxymethyl furfural [3]. The production of these inhibitors affect both a fermentation step (due to low conversion of sugars into ethanol) and a downstream processing step (due to low productivity). 
On the contrary to high temperature chemical treatment processes, moderate temperature treatment processes using alkaline hydroxide [5, 6] and AHP [6] have also been reported for softwood conversion. Using alkaline hydroxide treatment $(0.075 \mathrm{~g}$ of $\mathrm{NaOH}$ per g of biomass; processing temperature $=80^{\circ}-100^{\circ} \mathrm{C}$ for $2 \mathrm{~h}$ ) on softwood (particle size: less than $0.8 \mathrm{~mm}$ ) had no significant effect on the delignification, and the enzymatic glucan conversion stayed below 25\% [5]. Furthermore, the change in processing conditions of alkaline hydroxide treatment $\left(80 \mathrm{~g} \mathrm{~L}^{-1}\right.$ of $\mathrm{NaOH}$, equivalent to $0.8 \mathrm{~g} \mathrm{NaOH}$ per $\mathrm{g}$ of biomass; processing temperature $=70^{\circ} \mathrm{C}$ for $20-21 \mathrm{~h}$ ) on softwood (particle size: $0.125-0.50 \mathrm{~mm}$ ), removed up to $25 \%$ of the phenolic compounds and the enzymatic glucan conversion stayed up to $37.5 \%$ [6]. However, the use of AHP treatment ( $80 \mathrm{~g} \mathrm{~L}^{-1}$ of $\mathrm{NaOH}$ (equivalent to $0.8 \mathrm{~g} \mathrm{NaOH}$ per $\mathrm{g}$ of biomass) and $204 \mathrm{~g} \mathrm{~L}^{-1}$ of $\mathrm{H}_{2} \mathrm{O}_{2}$ (equivalent to $2.04 \mathrm{~g} \mathrm{H}_{2} \mathrm{O}_{2}$ per g of biomass); processing temperature $=70{ }^{\circ} \mathrm{C}$ for $20-21$ h) on softwood (particle size: $0.125-0.50 \mathrm{~mm}$ ), increased the delignification efficiency up to $60 \%$ with the enzymatic glucan conversion up to $60 \%$ [6]. Using herbaceous feedstock, AHP treatment can increase the enzymatic saccharification efficiency up to $90 \%$ [14]. In alkaline condition, hydrogen peroxide produces hydroxyl radicals $\left(\mathrm{OH}^{*}\right)$, superoxide anions $\left(\mathrm{O}_{2}{ }^{-}\right)$, hydroperoxide anions $\left(\mathrm{HO}_{2}^{-}\right)$, solvated electrons (aq. $\mathrm{e}^{-)}$and atmospheric oxygen $\left(\mathrm{O}_{2}\right)$ [15]. The generated hydrogen peroxide reactive species play a

$$
\begin{array}{ll}
\mathrm{HO}_{2}^{-}+\mathrm{H}_{2} \mathrm{O}+2 \mathrm{e}^{-} \leftrightarrow 3 \mathrm{OH}^{-} & {[16]} \\
\mathrm{OH}^{-}+\mathrm{e}^{-} \leftrightarrow \mathrm{OH}^{-} & {[17]} \\
\mathrm{O}_{2}+\mathrm{e}^{-} \leftrightarrow \mathrm{O}_{2}{ }^{-} & {[18]}
\end{array}
$$

critical role in the delignification of lignocellulosic feedstock, thereby increasing subsequent enzymatic saccharification [14, 19]. The scope of AHP treatment is limited to certain feedstock due to crystallinity, volatility of reaction with the increasing temperature, and safety concerns with a scale-up of the process [6, 19-20]. AHP treatment can be performed using potassium hydroxide $(\mathrm{KOH})$, sodium hydroxide $(\mathrm{NaOH})$, calcium hydroxide $\left(\mathrm{Ca}(\mathrm{OH})_{2}\right)$, and ammonium hydroxide $\left(\mathrm{NH}_{4} \mathrm{OH}\right)$. The efficacy of $\mathrm{NH}_{4} \mathrm{OH}$ with $\mathrm{H}_{2} \mathrm{O}_{2}$ decreases with the increasing crystallinity of lignocellulosic biomass [19]. $\mathrm{KOH}$ has both environmental and health benefits compared to $\mathrm{NaOH}$. The recovery of potassium ion $\left(\mathrm{K}^{+}\right)$in the form of potassium chloride $(\mathrm{KCl})$ and potassium citrate salts have applications in fertilizer, food and beverages, and pharmaceutical products development [21-22].

The objective of the present study was to compare the effect of solvent polarities of EHOs treatment ( $60 \%$ ethanol $+50 \mathrm{~g} \mathrm{~L}^{-1} \mathrm{KOH}+50 \mathrm{~g} \mathrm{~L}^{-1} \mathrm{H}_{2} \mathrm{O}_{2}$ with added deionized water), and AHP treatment $\left(50 \mathrm{~g} \mathrm{~L}^{-1} \mathrm{KOH}+50 \mathrm{~g} \mathrm{~L}^{-1} \mathrm{H}_{2} \mathrm{O}_{2}\right.$ with added deionized water) using GPWC. The generated pulps were analyzed through chemical composition and enzymatic saccharification efficiency. Furthermore, the four variables response surface methodology was examined to understand the effect of temperature, ethanol, $\mathrm{KOH}$, and $\mathrm{H}_{2} \mathrm{O}_{2}$ in the enzymatic saccharification of GPWC.

\section{Materials and Methods \\ 2.1. Pine Wood Chips Preparation}

Pine woods chips were received from Arbogen (Ridgeville, SC). The received pine wood chips were oven dried for 6 days at $40^{\circ} \mathrm{C}$. The moisture content of $10.5 \pm 0.6 \%$ of total biomass was measured. The dried chips $(2 \mathrm{~cm} \times 2.5 \mathrm{~cm} \times 0.75 \mathrm{~cm})$ were reduced to 0.5-1.0 mm size particles using a laboratory Wiley mill (Thomas Model 4 Wiley ${ }^{\circledR}$ Mill). The moisture content of the sieved GPWC was $0.1 \pm 0.0 \%$ before further analyses. 


\subsection{Chemical Treatments}

Chemical treatments formulation consisted of hydrogen peroxide $\left(350 \mathrm{~g} \mathrm{~L}^{-1} \mathrm{H}_{2} \mathrm{O}_{2}\right.$, $\mathrm{BDH}$ ), potassium hydroxide ( $85 \% \mathrm{KOH}$ purity, Alfa Aesar), ethanol, and deionized water. For chemical treatments, screw-capped 1 L media glass bottles (Pyrex) and a Parr reactor (Model 4553) were used similar to the previous research [19]. Initially, $8.07 \pm 0.03 \mathrm{~g}$ of GPWC was added with AHP and EHOs solvents in the ratio of 1:10 (w/v). AHP treatment formulation consisted of $4 \mathrm{~g}$ of $\mathrm{KOH}$ (equivalent to $50 \mathrm{~g} \mathrm{~L}^{-1}$ and $0.50 \mathrm{~g}$ per $\mathrm{g}$ of biomass), $11.4 \mathrm{~mL}$ of $\mathrm{H}_{2} \mathrm{O}_{2}$ (equivalent to $50 \mathrm{~g} \mathrm{~L}^{-1}$ and $0.50 \mathrm{~g}$ per $\mathrm{g}$ of biomass) and $64.6 \mathrm{~mL}$ of deionized water. Whereas, EHOs treatment formulation consisted of $48 \mathrm{~mL}$ of ethanol (equivalent to $60 \%$ of total solution), $4 \mathrm{~g}$ of $\mathrm{KOH}$ (equivalent to $50 \mathrm{~g} \mathrm{~L}^{-1}$ and $0.50 \mathrm{~g}$ per $\mathrm{g}$ of biomass), $11.4 \mathrm{~mL}$ of $\mathrm{H}_{2} \mathrm{O}_{2}$ (equivalent to $50 \mathrm{~g} \mathrm{~L}^{-1}$ and $0.50 \mathrm{~g}$ per $\mathrm{g}$ of biomass), and $16.6 \mathrm{~mL}$ of deionized water. Both, AHP and EHOs treatments were carried out at $78^{\circ} \mathrm{C}$ for $24 \mathrm{~h}$. After chemical treatments, the three consecutive hot water washes were performed. Each wash was corresponded to $200 \mathrm{~mL}$ of liquid. The chemically treated GPWC were retained using $0.15-0.18 \mathrm{~mm}$ sieve. At the end of the washing step, the retained biomass was squeezed (using a lemon squeezer) to remove excessive water. The obtained samples were used for chemical composition and enzymatic saccharification analyses. AHP and EHOs treatments were performed in five replicates such that two replicates for mass balance (including moisture content and chemical composition) and three replicates for enzymatic saccharification analyses.

\subsection{Analytical Methods}

National renewable energy laboratory (NREL) protocols were followed for the determination of carbohydrates, acid-insoluble and soluble lignin, ash, and extractive contents of GPWC [23-25]. The chemical composition of AHP and EHOs-treated GPWC were analyzed using HPLC (Shimadzu SIL-10AF, Palo Alto, CA) equipped with 355 RID (refractory index detector) and Bio-Rad Aminex $87 \mathrm{P}$ column (operated at $85^{\circ} \mathrm{C}$ ), using water as a mobile phase. The enzymatic saccharification process, response surface methodology (both chemical composition and enzymatic saccharification), and ethanol concentration (after EHOs treatment), were analyzed using HPLC equipped with 355 RID and Bio-Rad Aminex $87 \mathrm{H}$ column (operated at $65^{\circ} \mathrm{C}$ ), using $0.01 \mathrm{~N} \mathrm{H}_{2} \mathrm{SO}_{4}$ as a mobile phase. The moisture content of GPWC was determined by oven-drying method at $105^{\circ} \mathrm{C}$ to a constant weight. Cellulase enzyme activity (reported in FPU $\mathrm{mL}^{-1}$ ) was determined [26] using BioTeK ${ }^{\circledR}$ plate reader (BioTeK ${ }^{\circledR}$, Model Synergy HT) at $540 \mathrm{~nm}$.

\subsection{Response Surface Methodology}

The effects of variables such as ethanol content (\%), $\mathrm{KOH}$ content $\left(\mathrm{g} \mathrm{L}^{-1}\right), \mathrm{H}_{2} \mathrm{O}_{2}\left(\mathrm{~g} \mathrm{~L}^{-}\right.$ ${ }^{1}$ ), and operating temperature $\left({ }^{\circ} \mathrm{C}\right)$, on EHOs treatment formulation were studied through the four variables response surface methodology. A response surface methodology can be used to find a combination of levels or settings for four factors that affects GPWC conversion (resulted through a combined chemical composition and enzymatic saccharification analyses). A central composite design of the four factors (ethanol, $\mathrm{KOH}$, $\mathrm{H}_{2} \mathrm{O}_{2}$, and temperature) was used to create the data set for the response surface analysis. The central composite design with orthogonal coordinates defines the combinations of the four factors that are utilized in the present study. In this study, ethanol, $\mathrm{KOH}, \mathrm{H}_{2} \mathrm{O}_{2}$, and temperature had five levels (Table1). The levels of ethanol, $\mathrm{KOH}, \mathrm{H}_{2} \mathrm{O}_{2}$, and temperature were selected based on the factors EHOs treatments was developed as 
described in the results and discussion section. Using all possible combinations of these requires only $2 \mathrm{k}(\mathrm{k}-1)+\mathrm{C}_{\mathrm{o}}$ combinations, where $\mathrm{k}$ is the number of factors (4) and $\mathrm{C}_{0}$ is the number of "center" combinations (all four factors set at the middle level). In this study, with four factors and four center combinations, only 28 combinations were required (Table 1). GPWC of $8 \mathrm{~g}$ was utilized with each sample preparation (Table 1). The ratio of sample to solvent was 1:10 (w/v). Each treatment was performed in five replicates such that three replicates for composition and two replicates for enzyme hydrolysis analyses.

\section{Table 1 - Central composite design for EHOs treatment analysis.}

\subsection{Enzyme Hydrolysis \\ 2.5.1. AHP and EHOs-Treated GPWC}

Both AHP-treated and EHOs-treated GPWC were analyzed for the enzymatic saccharification using Accellerase ${ }^{\circledR}$ 1500. In $250 \mathrm{~mL}$ stopper conical flasks, AHP-treated GPWC $(6.2 \pm 0.3 \mathrm{~g}$ (dry basis) with moisture content of $70.8 \pm 0.6 \%$ of total wet biomass) and EHOs-treated GPWC (5.9 $\pm 0.2 \mathrm{~g}$ (dry basis) with moisture content of 74.5 $\pm 0.5 \%$ of total wet biomass) were added with $80 \mathrm{~mL}$ of $0.1 \mathrm{M}$ citric acid buffer $(\mathrm{pH} 4.8)$, 80.2 FPU (filter paper unit of Accellerase ${ }^{\circledR}$ 1500) per gram of biomass [27], along with $2.0 \mathrm{~mL}$ of sodium azide buffer solution (stock solution concentration $=20 \mathrm{~g} \mathrm{~L}^{-1}$ ). The flasks were incubated at $50{ }^{\circ} \mathrm{C}$ in a floor shaker incubator $(\mathrm{C} 25 \mathrm{KC}$, New Brunswick Scientific) at 250 revolutions per minute. Sample volumes of $1 \mathrm{~mL}$ were taken from the flasks at $0,24,48$, and $72 \mathrm{~h}$ of analyses. All samples were analyzed in three replicates.

\subsubsection{Response Surface Methodology}

For the response surface study, chemically treated samples were added with 40.1 FPU per gram of biomass, $1 \mathrm{~mL}$ of sodium azide buffer solution, followed by the addition of $75 \mathrm{~mL}$ of $0.1 \mathrm{M}$ citric acid buffer ( $\mathrm{pH} 4.8$ ). The sample flasks were incubated in the floor shaker incubator at $50{ }^{\circ} \mathrm{C}$ for $72 \mathrm{~h}$ with continuous stirring at 250 revolutions per minute. Samples volume of $1 \mathrm{~mL}$ were taken from the flasks at 0 and $72 \mathrm{~h}$ of analyses. All samples were analyzed in two replicates.

\subsection{Sugars Conversion}

The polysaccharide contents of untreated, EHOs-treated, and AHP-treated GPWC were analyzed using glucose, xylose, mannose, galactose and arabinose as standard sugars. Aminex-87 P column was utilized for the analysis. These sugars can be correlated to the polysaccharide contents of GPWC using the following relations.

Glucan $=$ Glucose produced $(\mathrm{g}) \times 0.9$ (hydration factor)

Xylan $=$ Xylose produced $(\mathrm{g}) \times 0.88$ (hydration factor)

Arabinan $=$ Arabinose produced $(\mathrm{g}) \times 0.88$ (hydration factor)

Galactan $=$ Galactose produced $(\mathrm{g}) \times 0.9$ (hydration factor)

Mannan = Mannose produced $(\mathrm{g}) \times 0.9$ (hydration factor)

The enzymatic saccharification and response surface analyses (both chemical composition followed by enzymatic saccharification) were analyzed using Aminex-87 $\mathrm{H}$ column. It was observed that the enzyme concentration affects the analysis using Aminex-87 P column (water as a mobile phase) due to increase in the operating pressure 
of column. To eliminate the pressure effect, Aminex-87 $\mathrm{H}$ column was utilized with 0.01 $\mathrm{N} \mathrm{H}_{2} \mathrm{SO}_{4}$ as a mobile phase. The similar retention times of xylose, mannose, and galactose were observed using 87-H column. Xylose-mannose-galactose concentration was analyzed using xylose as a standard. For chemical composition determination (for response surface methodology), xylose-mannose-galactose conversion factor of 0.88 was used for xylan-mannan-galactan content of GPWC. The enzymatic saccharification efficiencies such as glucan conversion, xylan-mannan-galactan conversion, and total polysaccharide conversion, were calculated using the following equations

Glucan conversion (\%)

$$
=\frac{\left(\text { Glucose concentration }\left(\mathrm{g} \mathrm{L}^{-1}\right)\right) \times \text { Liquid volume }(\mathrm{L}) \times 0.9}{\text { Glucan content }(\mathrm{g}) \text { of treated GPWC }} \times 100 \%
$$

Xylan-Mannan-Galactan conversion (\%)

$$
=\frac{\left[\begin{array}{c}
\left(\text { Xylose }- \text { Mannose }- \text { Galactose concentration }\left(\mathrm{g} \mathrm{L}^{-1}\right)\right) \\
\times \text { Liquid volume }(\mathrm{L}) \times 0.88
\end{array}\right]}{\text { Xylan }- \text { Mannan }- \text { Galactan content }(\mathrm{g}) \text { of treated GPWC }} \times 100 \%
$$

Total polysaccharide conversion (\%)

$$
=\frac{\left[\begin{array}{c}
(\text { Glucan conversion } \times \text { Glucan content })+ \\
(\text { Xylan }- \text { Mannan }- \text { Galactan conversion } \\
\times \text { Xylan }- \text { Mannan }- \text { Galactan content })
\end{array}\right]}{(\text { Glucan }+ \text { Xylan }- \text { Mannan }- \text { Galactan }) \text { contents }(\mathrm{g}) \text { of treated GPWC }} \times 100 \%
$$

Where, glucan, and xylan-mannan-galactan represented the available polysaccharide content during the enzyme hydrolysis of chemically treated GPWC.

\subsection{Ethanol Recovery}

Ethanol content in EHOs treatment (conditions: reactor volume $=3.85 \mathrm{~L}$; solid loading $=216 \mathrm{~g}$; solvent loading $=2.16 \mathrm{~L}$ consisted of $60 \%$ ethanol $+50 \mathrm{~g} \mathrm{~L}^{-1} \mathrm{KOH}+50 \mathrm{~g} \mathrm{~L}^{-1}$

$\mathrm{H}_{2} \mathrm{O}_{2}$, with volume adjusted using water; processing temperature $=78{ }^{\circ} \mathrm{C}$; processing time $=24 \mathrm{~h}$ ) was measured before and after the process using aqueous ethanol standards. After the treatment, the reactor vessel was cooled down to $60^{\circ} \mathrm{C}$ using a water-ice bucket and then released the pressure of the vessel. Before taking the final sample of the generated solvent mixture, the reactor vessel was cooled down to the room temperature $\left(25^{\circ} \mathrm{C}\right)$. The $\mathrm{pH}$ of the solvent mixture was adjusted to six (using anhydrous citric acid) before ethanol content analysis. Internal standard of $60 \%$ aqueous ethanol was used as a reference. Ethanol recovery was defined by the following relationship.

Ethanol recovery $(\%)$

$$
=\frac{\text { Final concentration of ethanol after EHOs treatment }}{\text { Initial concentration of ethanol before EHOs treatment }} \times 100 \%
$$

The final concentration of ethanol was analyzed with the external standard of diluted ethanol concentration with the moisture content of GPWC.

\subsection{Statistical Analysis}

Statistical analyses were performed using JMP ${ }^{\circledR}$ Pro software (Windows 10; version 12). Paired $t$-tests were applied for the comparative analysis of enzyme hydrolysis of EHOs-treated and AHP-treated GPWC at 0.05 significant level. The interaction of variables (temperature, ethanol, $\mathrm{KOH}$ and $\mathrm{H}_{2} \mathrm{O}_{2}$ ) were examined using the four variables 
response surface methodology with a second degree factorial analysis. The response surface methodology analyzes a design of statistical experiment, checks the adequacy of the model, estimates the regression coefficients, and predicts the optimal responses. The statistical significance of the model coefficients was determined by the analysis of the variance (ANOVA) combined with the application of Fisher's $F$ test. Statistical analyses of responses were included with glucan conversion, and total polysaccharide conversion. Average value was reported with a standard error.

\section{Results and Discussion \\ 3.1. Effect of Chemical Treatments on Enzymatic Digestibility of GPWC}

The effects of chemical treatments on GPWC were examined through a combination of chemical composition and enzymatic saccharification processes (Table 2 and Fig. 1). At $78{ }^{\circ} \mathrm{C}$, the delignification efficiency/biomass recovery of $43 / 73 \%$ and $49 / 77 \%$ were measured for AHP-treated and EHOs-treated GPWC, respectively (Table 2). A significant difference was found between the enzymatic saccharification efficiencies of AHP-treated and EHOs-treated GPWC (Fig. 1). The enzymatic saccharification of AHP-treated GPWC was resulted in $61.84 \pm 1.08 \%, 31.13 \pm 2.14 \%$, and $54.73 \pm 0.57 \%$ through conversions of glucan, xylan-mannan-galactan, and total polysaccharide, respectively. Whereas, the enzymatic saccharification of EHOs-treated GPWC was resulted in $75.18 \pm$ $0.85 \%, 33.28 \pm 2.34 \%$, and $66.07 \pm 0.46 \%$ through conversions of glucan, xylan-mannangalactan, and total polysaccharide, respectively. The combined xylose-mannose-galactose yields of $3.86 \pm 0.27 \mathrm{~g} \mathrm{~L}^{-1}$ and $3.64 \pm 0.26 \mathrm{~g} \mathrm{~L}^{-1}$ were measured for AHP-treated and EHOs-treated GPWC, respectively.

\section{Table 2 - Effect of chemical treatments on GPWC.}

\section{Fig. 1 - Enzyme hydrolysis of AHP-treated and EHOs-treated GPWC using Accellerase $^{\circledR} 1500$ with the resulted sugar yields and their conversions.}

In the present study, the concentration of reactants in AHP and EHOs treatments for GPWC were selected based on the previous study on the comparative crystallinity of softwood with sugarcane bagasse [2]. The difference in the crystallinity of untreated softwood $(83.8 \%)$ compared to untreated sugarcane bagasse $(71.8 \%)$ indicated the usage of a higher concentration of alkaline hydroxide in the chemical treatment process [2, 6]. For that reason, approximately two fold increased in concentration of KOH in both AHP and EHOs treatments was selected based on the available literature on alkali treatment using sugarcane bagasse [28-29]. The concentration of $\mathrm{H}_{2} \mathrm{O}_{2}$ in AHP and EHOs treatments was based on the dry weight of GPWC as described by Gould [14] and was selected equivalent to $\mathrm{KOH}$ concentration. The ethanol concentration $(60 \%$ of the total solution) in EHOs treatment was selected based on lignin solubility [30], minimum water usage, and for cellulose-hemicellulose retention [31]. The temperature of $78^{\circ} \mathrm{C}$ was selected for both chemical treatments (AHP and EHOs) to achieve moderate activation energy for solvents [12], applicability of solvent mixtures, and to compare analysis of the processes. The processing time of $24 \mathrm{~h}$ was selected for both AHP and EHOs treatments based on the previous conducted studies using alkaline hydroxide and AHP treatments [5$6,14,19]$.

The efficiency of chemical treatment method depends on solvent polarity, processing temperature, and time. The solvent polarity assists with solubilization of phenolic 
compounds (by extraction), thereby reducing the crystallinity of cellulose and hemicellulose contents of GPWC. A similar phenomenon was examined using AHP and EHOs treatments. The structural-chemical composition of GPWC using a sulfuric acid hydrolysis [25] indicated the quantitative effect of the applied chemical treatments. The sulfuric acid hydrolysis analyzed the chemical composition without distinguishing crystalline and amorphous contents of GPWC resulting through the applied chemical treatments. The chemical composition analysis along with the enzymatic saccharification analysis represented both qualitative and quantitative effects of accessible polysaccharide contents of GPWC. Moreover, the enzymatic saccharification using Accellerase ${ }^{\circledR} 1500$ mainly hydrolyzes an amorphous glucan content of GPWC [6]. The enzymatic conversions of glucan and total polysaccharide of GPWC represented the specific and overall effect of Accellerase ${ }^{\circledR} 1500$, respectively. The enzymatic conversion of glucan up to $70 \%$ is considered a bench-mark for any process to be commercialized with the economics of the process (such as safety of the process, operating temperature, operating time, biomass conversion efficiency, production of multiple valuable by-products, integration of different unit operations, cost of chemicals, and initial capital investment). The enzymatic glucan conversion efficiency up to $70 \%$ had been reported using soaking in aqueous ammonia treatment (ammonium hydroxide concentration $=150-200 \mathrm{~g} \mathrm{~L}^{-1}$; operating temperature $=60^{\circ}-80^{\circ} \mathrm{C}$ for 12-24 h) using herbaceous crops [32-35] and currently in commercialization phase for cellulosic ethanol production (leading by Danisco-DuPont). Jain and co-researchers [36] have described the economics of EHOs treatment $\left(25 \mathrm{~g} \mathrm{~L}^{-1} \mathrm{KOH}(0.27 \mathrm{~g}\right.$ of $\mathrm{KOH}$ per $\mathrm{g}$ of dried biomass $), 25 \mathrm{~g} \mathrm{~L}^{-1} \mathrm{H}_{2} \mathrm{O}_{2}(0.27 \mathrm{~g}$ of $\mathrm{H}_{2} \mathrm{O}_{2}$ per $\mathrm{g}$ of dried biomass), $250 \mathrm{~g} \mathrm{~L}^{-1}$ water and $525 \mathrm{~g} \mathrm{~L}^{-1}$ ethanol (70\% of the total volume of solvent) at $75^{\circ} \mathrm{C}$ for $1 \mathrm{~h}$ ) compared to soaking in aqueous ammonia treatment (150 g L ${ }^{-1} \mathrm{NH}_{4} \mathrm{OH}$ solution (1.6 $\mathrm{g} \mathrm{NH}_{4} \mathrm{OH}$ per g of dried biomass) at $75{ }^{\circ} \mathrm{C}$ for $15 \mathrm{~h}$ ) using sugarcane bagasse in terms of reactor loadings, enzyme saccharification at high substrate loadings, electricity production (through generated pressure), development of desalination process (through development of a self-sustainable integrated biorefinery), and anticancer drug development (using lignin fraction).

\subsection{Effect of EHOs treatment on GPWC}

Based on the achieved results using EHOs treatment of GPWC, the optimization of variables (temperature, ethanol concentration, $\mathrm{KOH}$ concentration, and $\mathrm{H}_{2} \mathrm{O}_{2}$ concentration) were considered within the range that described the effect of the initial selected parameters with the maximum glucan conversion (> 70\%) as shown in table 1. Simple statistics of the response surface method using conversions of glucan and total polysaccharide of GPWC as responses are shown in Table 3. The similar R-square values (of 0.96) were examined between the experimental and model based values for conversions of glucan and total polysaccharide of GPWC (Fig. 2). The model based values were estimated from the interaction of temperature, ethanol, $\mathrm{KOH}$ and $\mathrm{H}_{2} \mathrm{O}_{2}$ during the enzymatic saccharification of chemically treated GPWC. The model based values were calculated using the following relationships.

\section{Glucan conversion $(\%)$}

$$
\begin{aligned}
= & 54.29+1.62 \times(\mathrm{Temp})+17.50 \times(\mathrm{KOH})+3.37 \times\left(\mathrm{H}_{2} \mathrm{O}_{2}\right) \\
& +1.72 \times(\text { Temp }) \times\left(\mathrm{H}_{2} \mathrm{O}_{2}\right)+3.21 \times(\mathrm{KOH}) \times\left(\mathrm{H}_{2} \mathrm{O}_{2}\right) \\
& -4.50 \times(\text { Temp }) \times(\mathrm{Temp})-4.43 \times(\text { Ethanol }) \times(\text { Ethanol }) \\
& -6.06 \times(\mathrm{KOH}) \times(\mathrm{KOH})-6.55 \times\left(\mathrm{H}_{2} \mathrm{O}_{2}\right) \times\left(\mathrm{H}_{2} \mathrm{O}_{2}\right)
\end{aligned}
$$




$$
\begin{aligned}
= & 41.59+2.30 \times(\mathrm{Temp})+13.96 \times(\mathrm{KOH})+2.74 \times\left(\mathrm{H}_{2} \mathrm{O}_{2}\right) \\
& +2.51 \times(\mathrm{Temp}) \times(\mathrm{KOH})+1.61 \times(\mathrm{Temp}) \times\left(\mathrm{H}_{2} \mathrm{O}_{2}\right)+2.69 \times \\
& (\mathrm{KOH}) \times\left(\mathrm{H}_{2} \mathrm{O}_{2}\right)-3.28 \times(\mathrm{Temp}) \times(\mathrm{Temp})-3.35 \times(\text { Ethanol }) \times \\
& (\text { Ethanol })-4.20 \times(\mathrm{KOH}) \times(\mathrm{KOH})-4.48 \times\left(\mathrm{H}_{2} \mathrm{O}_{2}\right) \times\left(\mathrm{H}_{2} \mathrm{O}_{2}\right)
\end{aligned}
$$

Table 3 - Analysis of variance (ANOVA) for the quadratic model resulted from glucan conversion $(\%)$ and total polysaccharide conversion (\%) of GPWC.

Fig. 2 - Analysis of enzymatic saccharification efficiencies of actual values vs. predicted values for conversions of glucan and total polysaccharide of GPWC using Accellerase $^{\circledR} 1500$.

To understand the interaction of different variables in EHOs treatment formulation, the center points of temperature $\left(48^{\circ}, 68^{\circ} \mathrm{C}\right)$, ethanol $(15,45 \%), \mathrm{KOH}\left(12.5,37.5 \mathrm{~g} \mathrm{~L}^{-1}\right)$ and $\mathrm{H}_{2} \mathrm{O}_{2}\left(12.5,37.5 \mathrm{~g} \mathrm{~L}^{-1}\right)$ were analyzed through conversions of glucan and total polysaccharide of GPWC (Figs. 3 and 4a-b). In EHOs treatment formulation, the concentration of $\mathrm{KOH}\left(>37.5 \mathrm{~g} \mathrm{~L}^{-1}\right)$ had the most significant effect in GPWC conversion (Figs. 3, 4a-b, and 5). In softwood, cellulose mainly occurs in the polymorph form of cellulose I (crystalline) and inaccessible in the native form during enzymatic saccharification [37]. Cellulose I can be converted to cellulose II (amorphous) through regeneration and mercerization processes using $\mathrm{KOH}$ solution that enhances cellulose accessibility [38]. The higher pKa values of $\mathrm{KOH}$ (pKa value $=16$ ) [39] compared to cellulosic hydroxyl groups ( $\mathrm{pKa}$ value $=14$ ) [40] would increase the solubility of GPWC. A pKa value represents the strength of acid solution and is directly proportional to Gibbs energy change [41]. The maximum concentration of $\mathrm{KOH}$ in optimization of EHOs treatment was measured at $58.2 \mathrm{~g} \mathrm{~L}^{-1}$ (Figs. 6 and $7 \mathrm{a}-\mathrm{b}$ ). However, the concentration of $\mathrm{KOH}$ in EHOs treatment to be effective for GPWC conversion, a significant concentration of $\mathrm{H}_{2} \mathrm{O}_{2}\left(>12.5 \mathrm{~g} \mathrm{~L}^{-1}\right)$ would be required (Figs. 3 and 5). The mixing of $\mathrm{KOH}$ with $\mathrm{H}_{2} \mathrm{O}_{2}$ increased both $\mathrm{pH}$ of the solvent [42] and the molecular dissociation of $\mathrm{H}_{2} \mathrm{O}_{2}$ (pKa value 11.6) [39]. The dissociation of $\mathrm{H}_{2} \mathrm{O}_{2}$ is both $\mathrm{pH}$ and temperature dependent. Moreover, the dissociation of $\mathrm{H}_{2} \mathrm{O}_{2}$ (in alkaline $\mathrm{pH}$ ) increased with the increasing temperature (Fig 3). $\mathrm{H}_{2} \mathrm{O}_{2}$ have a half shelf life of $1 \mathrm{~h}\left(\right.$ at $80{ }^{\circ} \mathrm{C}$ ) to $5 \mathrm{~h}$ (at 60 $\left.{ }^{\circ} \mathrm{C}\right)$ [43-44]. The temperature and $\mathrm{pH}$ dependency of $\mathrm{H}_{2} \mathrm{O}_{2}$ would be a potential reason corresponding to the optimal concentration of $\mathrm{H}_{2} \mathrm{O}_{2}$ and the optimal temperature at $42.7 \mathrm{~g}$ $\mathrm{L}^{-1}$ and $75.4^{\circ} \mathrm{C}$, respectively (Figs. 6 and $7 \mathrm{a}-\mathrm{b}$ ).

Fig. 3 - Interaction profiles of temperature, ethanol, $\mathrm{KOH}$, and $\mathrm{H}_{2} \mathrm{O}_{2}$ during the enzymatic saccharification of GPWC using Accellerase ${ }^{\circledR} 1500$.

Fig. 4a - Surface profilers for glucan conversion (\%) as functions of temperature (at $58{ }^{\circ} \mathrm{C}$ ), ethanol (at 30\%), $\mathrm{KOH}\left(\right.$ at $25 \mathrm{~g} \mathrm{~L}^{-1}$ ) and $\mathrm{H}_{2} \mathrm{O}_{2}\left(\right.$ at $\left.25 \mathrm{~g} \mathrm{~L}^{-1}\right)$ during the enzymatic saccharification of GPWC using Accellerase ${ }^{\circledR} 1500$.

Fig. 4b - Surface profilers for total polysaccharide conversion (\%) as functions of temperature (at $58{ }^{\circ} \mathrm{C}$ ), ethanol (at $30 \%$ ), $\mathrm{KOH}\left(\right.$ at $25 \mathrm{~g} \mathrm{~L}^{-1}$ ) and $\mathrm{H}_{2} \mathrm{O}_{2}\left(\right.$ at $25 \mathrm{~g} \mathrm{~L}^{-1}$ ) during the enzymatic saccharification of GPWC using Accellerase ${ }^{\circledR} 1500$. 
Fig. 5 - Sorted estimate parameters for glucan conversion (\%) and total polysaccharide conversion $(\%)$ resulted through the interactions of temperature (Temp), ethanol (EtOH), $\mathrm{KOH}$, and $\mathrm{H}_{2} \mathrm{O}_{2}$ during the enzymatic saccharification of GPWC.

Fig. 6 - Optimized EHOs treatment conditions resulted through the enzymatic saccharification of GPWC using Accellerase ${ }^{\circledR} 1500$.

Fig. 7a - Optimized surface profilers for glucan conversion (\%) as functions of temperature (at $64.2{ }^{\circ} \mathrm{C}$ ), ethanol (at 32.1\%), $\mathrm{KOH}\left(\right.$ at $46.6 \mathrm{~g} \mathrm{~L}^{-1}$ ) and $\mathrm{H}_{2} \mathrm{O}_{2}$ (at 34.5 $\mathrm{g} \mathrm{L}^{-1}$ ) during the enzymatic saccharification of GPWC using Accellerase ${ }^{\circledR} 1500$.

Fig. 7b - Optimized surface profilers for total polysaccharide conversion (\%) as functions of temperature (at $75.4^{\circ} \mathrm{C}$ ), ethanol (at 35.7\%), $\mathrm{KOH}\left(\right.$ at $\left.58.2 \mathrm{~g} \mathrm{~L}^{-1}\right)$ and $\mathrm{H}_{2} \mathrm{O}_{2}$ (at $\left.42.7 \mathrm{~g} \mathrm{~L}^{-1}\right)$ during the enzymatic saccharification of GPWC using Accellerase $^{\circledR} 1500$.

Performing a Parr reactor study, the exothermic reaction of $\mathrm{KOH}$ and $\mathrm{H}_{2} \mathrm{O}_{2}$ built up the pressure to 11 bar to 15.2 bar at $60{ }^{\circ}$ to $80^{\circ} \mathrm{C}$, respectively, in the enclosed vessel (conditions: reactor volume $=3.8 \mathrm{~L}$; solid loading $=216 \mathrm{~g}$; solvent loading $=2.16 \mathrm{~L}$ consisted of $60 \%$ ethanol $+50 \mathrm{~g} \mathrm{~L}^{-1} \mathrm{KOH}+50 \mathrm{~g} \mathrm{~L}^{-1} \mathrm{H}_{2} \mathrm{O}_{2}$ with added deionized water). The pressure in the reactor vessel was increased slowly and gradually after 5 minutes of $\mathrm{H}_{2} \mathrm{O}_{2}$ addition. Under the similar composition of EHOs-solvent using GPWC at $78^{\circ} \mathrm{C}$, the maximum pressure of 1.6-2.1 bar was calculated (using the ideal gas law) in 1L media bottles (sample $8 \mathrm{~g}$; solvent: sample ratio of 10:1(vol/wt)). Under the alkaline and pressurized conditions, concentration of ethanol $(\mathrm{pKa}$ value $=15.5)[16]$ provided the stability to water molecules (pKa value $=14$ ) [16] and maximized the interaction with GPWC [37-38]. The basicity of the solvent mixture increases with the mixing of ethanol and water [45]. In addition, the basicity of $\mathrm{H}_{2} \mathrm{O}_{2}$ solution also remained dominant at the lower concentration (up to 0.4 mole fraction of $\mathrm{H}_{2} \mathrm{O}_{2}$ ) in aqueous ethanol [45]. Different physiochemical properties of ethanol (such as polarity, thermal conductivity, viscosity and surface tension) compared to water have importance in GPWC conversion. The lower polarity of ethanol (dipole moment $=5.64 \times 10^{-30} \mathrm{C} \mathrm{m}$, dielectric constant $=25.3$ at 20 ${ }^{\circ} \mathrm{C}$, as in EHOs treatment) compared to water (dipole moment $=6.19 \times 10^{-30} \mathrm{C} \mathrm{m}$, dielectric constant $=80.1$ at $20^{\circ} \mathrm{C}$, as in AHP treatment) could lead to a higher delignification of GPWC [16]. In EHOs treatment, the interaction of GPWC with the solvent occurs through the formation of ethoxide ion and hydroxide ion in the alkaline condition. Whereas, in AHP treatment, the interaction between the solvent and GPWC mainly occurs due to the formation of hydroxyl ions. The movement of ionic species (hydroxyl and ethoxide ions) govern through the conductivity of a solvent. The thermal conductivities of pure water and pure ethanol differ between $0.61 \mathrm{~W} \mathrm{~m}^{-1} \mathrm{~K}^{-1}$ (at $25^{\circ} \mathrm{C}, 1$ bar) to $0.66 \mathrm{~W} \mathrm{~m}^{-1} \mathrm{~K}^{-1}$ (at $75{ }^{\circ} \mathrm{C}, 1 \mathrm{bar}$ ), and $0.17 \mathrm{~W} \mathrm{~m}^{-1} \mathrm{~K}^{-1}$ (at $25^{\circ} \mathrm{C}, 1 \mathrm{bar}$ ) to $0.15 \mathrm{~W} \mathrm{~m}^{-}$ ${ }^{1} \mathrm{~K}^{-1}$ (at $75^{\circ} \mathrm{C}, 1 \mathrm{bar}$ ), respectively [16]. The lower thermal conductivity of ethanol solvent (as in EHOs treatment) also indicated that the temperature dependency of ionic species mobility would be smaller compared to water solvent (as in AHP treatment). The thermal conductivity of ethanol (in EHOs treatment) would be a potential reason for the slower and gradual rise in pressure after 5 minutes of $\mathrm{H}_{2} \mathrm{O}_{2}$ addition in the enclosed 
vessel. The concentration of ethanol in EHOs treatment not only slowed down the exothermic reaction (due to $\mathrm{KOH}$ and $\mathrm{H}_{2} \mathrm{O}_{2}$ ) but also provided safety in the process which is critical with the scale-up studies. Furthermore, both viscosity and surface tension of the solvent have a role in the transportation and interaction of ionic species with an inner matrix of GPWC. The viscosities of pure water and pure ethanol differ between $0.89 \mathrm{mPa} \mathrm{s}\left(\right.$ at $25^{\circ} \mathrm{C}$ ) to $0.38 \mathrm{mPa} \mathrm{s}\left(\right.$ at $75^{\circ} \mathrm{C}$ ), and $1.07 \mathrm{mPa} \mathrm{s}\left(\right.$ at $25^{\circ} \mathrm{C}$ ) to 0.48 $\mathrm{mPa} \mathrm{s}\left(\right.$ at $\left.75^{\circ} \mathrm{C}\right)$, respectively [16]. Whereas, the surface tensions of pure water and pure ethanol differ between 72.75 (at $20{ }^{\circ} \mathrm{C}$ ) to $62.67 \mathrm{mN} \mathrm{m}^{-1}$ (at $80{ }^{\circ} \mathrm{C}$ ), and $22.39 \mathrm{mN} \mathrm{m}^{-1}$ (at $20{ }^{\circ} \mathrm{C}$ ) to $18.23 \mathrm{mN} \mathrm{m}^{-1}$ (at $70^{\circ} \mathrm{C}$ ), respectively [46]. In the present study, the use of $30 \%$ aqueous ethanol was found effective in the controlled foaming phenomenon during the chemical treatment processes. The controlled foaming is the prerequisite for the scale-up studies from lab to pilot to commercial scale. For $30 \%$ aqueous ethanol, the surface tension of the solvent varies in between $25 \mathrm{mN} \mathrm{m}^{-1}$ (at $20^{\circ} \mathrm{C}$ ) to $27 \mathrm{mN} \mathrm{m}^{-1}$ (at $50{ }^{\circ} \mathrm{C}$ ) [47]. The optimal concentration of ethanol in EHOs treatment was measured at $35.7 \%$ (Fig. 6). The reduction in the surface tension would be correlated to the decrease of hydrogen bonding capability in aqueous ethanol. The reduced surface tension and the increased pressure would enhance both the conversions of glucan and total polysaccharide of GPWC [38, 48-51]. The use 30\%-40\% of aqueous ethanol had a significant effect on the swelling of cellulose nanostructure that influences the enzymatic saccharification of lignocellulosic biomass [49-50]. Moreover, the increased content of ethanol $(\geq 70 \%)$ in EHOs-solvent formulation recover potassium ion as a precipitated salt [52].

After EHOs treatment (conditions: reactor volume $=3.8 \mathrm{~L}$; solid loading $=216 \mathrm{~g}$; solvent loading $=2.16 \mathrm{~L}$ consisted of $60 \%$ ethanol $+50 \mathrm{~g} \mathrm{~L}^{-1} \mathrm{KOH}+50 \mathrm{~g} \mathrm{~L}^{-1} \mathrm{H}_{2} \mathrm{O}_{2}$ with added water; treatment time $=24 \mathrm{~h}$; processing temperature $75^{\circ} \mathrm{C}$ ), the ethanol recovery of $99.2 \%$ was measured. Li and co-researchers [53] have reported that up to $100 \mathrm{~g} \mathrm{~L}^{-1}$ of $\mathrm{NaOH}$ would be utilized along with ethanol during the chemical treatment (temperature $=$ $100{ }^{\circ} \mathrm{C}$, processing time $=30 \mathrm{~min}$ ) with $99.5 \%$ of ethanol recovery. Ethanol can act as either a proton acceptor (in acidic condition) or a proton donor (in alkaline condition as in the present study). The stability of ethanol molecule decreases in the acidic $\mathrm{pH}$ compared to the alkaline $\mathrm{pH}$ conditions [54-55]. The recovery of ethanol in the alkaline condition (as in EHOs treatment) also indicated that $\mathrm{H}_{2} \mathrm{O}_{2}$ had no reactivity with ethanol (Fig. 5). Furthermore, the lower polarity of $\mathrm{H}_{2} \mathrm{O}_{2}$ molecule (dipole moment $=5.25 \times 10^{-30} \mathrm{C} \mathrm{m}$, dielectric constant $=74.6$ at $17^{\circ} \mathrm{C}$ ) [16] compared to water, stabilizes in aqueous ethanol [45]. In EHOs treatment, the physiochemical properties of aqueous ethanol, and its interdependency on $\mathrm{KOH}$ and $\mathrm{H}_{2} \mathrm{O}_{2}$ would be a potential reason for the obtained negative curvatures (generated through four variables response surface analysis) (Fig. 5). A further research is required to determine the physiochemical changes in GPWC after EHOs and AHP treatments using X-ray diffraction (for crystallinity), and scattering electron microscopy (for structural changes).

The optimal GPWC conversions of glucan and total polysaccharide were predicted at $71.2 \%$ (conditions: $32.1 \%$ ethanol $+46.6 \mathrm{~g} \mathrm{~L}^{-1} \mathrm{KOH}+34.5 \mathrm{~g} \mathrm{~L}^{-1} \mathrm{H}_{2} \mathrm{O}_{2}$ at $64.2{ }^{\circ} \mathrm{C}$ for 24 h) and at $64.2 \%$ (conditions: $35.7 \%$ ethanol $+58.2 \mathrm{~g} \mathrm{~L}^{-1} \mathrm{KOH}+42.7 \mathrm{~g} \mathrm{~L}^{-1} \mathrm{H}_{2} \mathrm{O}_{2}$ at 75.4 ${ }^{\circ} \mathrm{C}$ for $24 \mathrm{~h}$ ), respectively. Moreover, the optimal conversions of glucan and total polysaccharide were reported in $95 \%$ and $87 \%$ confidence intervals, respectively (Fig. 6). The lower confidence interval for the total polysaccharide conversion would be resulted due to both detection of different sugars (such as xylose, mannose and galactose) at the single peak (using Biorad Aminex 87-H column), and the lower hemicellulose conversion 
efficiency of Accellerase ${ }^{\circledR}$ 1500. The interdependency of chemical composition on the enzymatic saccharification would affect analysis of the total polysaccharide conversion of were found comparable to the initial EHOs treatment condition $\left(60 \%\right.$ ethanol $+50 \mathrm{~g} \mathrm{~L}^{-1}$ $\mathrm{KOH}+50 \mathrm{~g} \mathrm{~L}^{-1} \mathrm{H}_{2} \mathrm{O}_{2}$ at $78{ }^{\circ} \mathrm{C}$ for $24 \mathrm{~h}$ ). The difference between obtained results would be explained on the basis of different enzyme loadings used in the preliminary study (using EHOs and AHP treatments at 80.2 FPU/g of biomass) and the response surface study (at $40.1 \mathrm{FPU} / \mathrm{g}$ of biomass). The use of optimal enzyme mixture (blend of xylanase with cellulase) would be useful in the further optimization of EHOs-treatment conditions compared to Accellerase ${ }^{\circledR} 1500$ alone.

The generated pressure in EHOs treatment (conditions: reactor volume $=3.8 \mathrm{~L}$; solid loading $=216 \mathrm{~g}$; solvent loading $=2.16 \mathrm{~L}$ consisted of $60 \%$ ethanol $+50 \mathrm{~g} \mathrm{~L}^{-1} \mathrm{KOH}+50$ $\mathrm{g} \mathrm{L}^{-1} \mathrm{H}_{2} \mathrm{O}_{2}$ with added water; treatment time $=24 \mathrm{~h}$; processing temperature $75^{\circ} \mathrm{C}$ ) was equivalent to the processing pressure of the Kraft process (at $160{ }^{\circ}$ to $180{ }^{\circ} \mathrm{C}$ ). In the paper pulp industry, a chemical treatment vessel is pressurized using oxygen or air to improve the delignification process. The application of EHOs treatment eliminated the external pressure requirement in the temperature ranges of $64^{\circ}-78^{\circ} \mathrm{C}$. The lower temperature is less energy intensive and would be useful in the biorefinery operations. However, a further research is required with different particle size distribution of GPWC ( $<0.15 \mathrm{~mm}, 0.15 \mathrm{~mm}-0.25 \mathrm{~mm}, 0.25 \mathrm{~mm}-0.5 \mathrm{~mm}$ ), chemical treatment processing time ( $1 \mathrm{~h}-5 \mathrm{~h}$, based on $\mathrm{H}_{2} \mathrm{O}_{2}$ shelf life), and reactor loading (at $20 \%, 40 \%, 60 \%$, and $80 \%$, to determine effective ethanol concentration under the pressurized conditions and for safety concerns of the process) in the optimal GPWC conversion before implication of EHOs treatment at the commercial level. The lignin produced during EHOs treatment process would have commercial application in the formation of carbon fibers and is subjected to further research $[13,56]$. Integration of EHOs treatment technology with biofuel development would have better environmental outcomes. The integrated paper pulp and biofuel biorefinery could save up to $20 \%$ in the energy lost [57]. The fact that ethanol, $\mathrm{KOH}$, and $\mathrm{H}_{2} \mathrm{O}_{2}$ are eco-friendly compounds, and the proper recycling of the solvent mixtures (after treatment) makes EHOs solvent system interesting and beneficial for large scale applications.

\section{Conclusions}

The very first time EHOs treatment was performed with GPWC. The glucan conversion efficiency of GPWC increased with the application of EHOs treatment compared to AHP treatment. The enzymatic saccharification of EHOs-treated GPWC had exceeded $70 \%$ of the total glucan conversion which is critical in lignocellulosic biomass based biorefinery development. Moreover, the utilization of multiple lignocellulosic feedstocks (ranging from woods to agriculture residues) using EHOs treatment method (with varying composition of solvent based on the crystallinity of lignocellulosic biomass) provided both the flexibility and continuity of biorefinery operation compared to soaking in aqueous ammonia treatment. Furthermore, the examined four variables response surface methodology provided the statistical optimization of EHOs treatment. The use of ethanol content up to $36 \%$ in EHOs solvent formulation had the most significant effect in the controlled foaming and would be useful in further scale-up studies. 


\section{Author and Co-Authors Contributions}

Author Arpan Jain conceptualized the research, worked on the research, and wrote the manuscript. William C Bridges assisted with the statistical analysis. Karl Kelly was the primary investigator on the project and managed the research project.

\section{Competing Interests}

The author and co-authors declare that they have no competing interests.

\section{Acknowledgements}

We would like to thank US department of energy for providing funding for this research (Award No. DE-FG36-08GO88071, and the project title "BioEthanol Collaborative"). We would like to thank Dr. Waye Chao (Forestry Department, Clemson University, Clemson, SC, USA) for the preprocessing of pine wood chips. We would like to thank Dr. Terry $\mathrm{H}$ Walker for providing the lab facility for the conducted research work. Dr. Terry H Walker had acquired $20 \%$ of inventorship (as a second inventor) in the filed patent application "Pretreatment composition for biomass conversion process" based on the provided lab facility. We would like to thank Dr. Sarah Harcum (Bioengineering Department, Clemson University, Clemson, SC, USA) for her time to review this manuscript and suggestions.

\section{References}

[1] Galbe M, Zacchi G. A review of the production of ethanol from softwood. Appl Microbiol Biotechnol 2002; 59:618-628.

[2] Wang W, Zhuang X, Yuan Z, Yu Q, Qi W, Wang Q, et al. Effect of structural changes on enzymatic hydrolysis of eucalyptus, sweet sorghum bagasse, and sugarcane bagasse after liquid hot water pretreatment. Bioresources 2012; 7(2):2469-2482.

[3] Sannigrahi P, Miller SJ, Ragauskas AJ. Effects of organosolv pretreatment and enzymatic hydrolysis on cellulose structure and crystallinity in Loblolly pine. Carbohydr Res 2010; 345:965-970.

[4] Miranda I, Pereira H. Kinetics of ASAM and Kraft Pulping of Eucalypt Wood (Eucalyptus globulus). Holzforschung 2002; 56:85-90.

[5] Mirahmadi K, Kabir MM, Jeihanipour A, Karimi K, Taherzadeh MJ. Alkaline pretreatment of spruce and birch to improve bioethanol and biogas production. Bioresources 2010; 5:928-938.

[6] Hideno A, Kawashima A, Morita M, Honda K, Endo T. Alkaline-peroxide treatment for enzymatic hydrolysis of Japanese Cypress (Chamaecyparis obtuse). J Jpn Inst Energy 2013; 92:1197-1204.

[7] Gil M, Ramos I, Arauzo I, Romá J. Characterization of a biomass milling pilot plant. 2009. 8 p. http://www.bioscale.es/wp-content/uploads/downloads/2014/04/Characterization-ofa-Biomass-Milling-Pilot-Plant.pdf

[8] Miao Z, Grift TE, Hansen AC, Ting KC. Energy requirement for communution of biomass in relation to particle physical properties. Ind Crops Prod 2011; 33:504-513.

[9] Muurinen E. Organosolv pulping- a review and distillation study related to peroxyacid pulping [Thesis]. Oulu (Finland): University of Oulu; 2000.

[10] Sannigrahi P, Ragauskas AJ. Chapter 10: Fundamentals of biomass pretreatment by fractionation. In: Wyman CE, editor. Aqueous pretreatment of plant biomass for biological and chemical conversion to fuels and chemicals. John Wiley \& Sons Ltd; 
2013. p. 201-222.

[11] Hart PW, Rudie AW. Anthraquinone - a review of the rise and fall of a pulping catalyst. Tappi J 2014; 13(10): 23-31.

[12] Mantanis IG. Swelling of lignocellulosic materials in water and organic liquids [Dissertation]. Madison (WI): University of Wisconsin-Madison;1994.

[13] Luo J. Lignin based carbon fiber [Thesis]. Orono (ME): University of Maine; 2010.

[14] Guald JM. Alkaline peroxide delignification of agricultural residues to enhance enzymatic saccharification. Biotechnol Bioeng 1984; 26(1):46-52.

[15] Petri BG, Watts RJ, Teel AL, Huling SG, Brown RA. Chapter 2: Fundamental of ISCO using hydrogen peroxide. In: Siegrist RL, Crimi M, Simpkin TJ, editors. In situ chemical oxidation for groundwater remediation. SERDP/ESTCP environmental remediation technology. Springer. 2011; 3:33-88.

[16] Lide DR, ed. CRC handbook of chemistry and physics. Boca Raton, FL; CRC Press: 2005.

[17] Bossmann SH, Oliveros E, Gob S, Siegwart S, Dahlen EP, Payawan L, et al. New evidence against hydroxyl radicals as reactive intermediates in the thermal and photochemically enhanced Fenton's reaction. J Phys Chem 1998; 102(28):5542-5550.

[18] Afanas'ev IB. Superoxide ion: chemistry and biological implications. Boca Raton, FL: CRC press; 1989.

[19] Gupta R. Alkaline pretreatment of biomass for ethanol production and understanding the factors influencing the cellulose hydrolysis [Dissertation]. Auburn (AL): Auburn University; 2008.

[20] Hart PW, Houtman C, Hirth K. Hydrogen peroxide and caustic soda: dancing with a dragon while bleaching. Tappi J 2013; 12(7): 59-65.

[21] Magen H. Potassium chloride in fertigation. 7th International Conference on Water and Irrigation. Tel Aviv, Israel; 1996: p.13-16. http://www.iclfertilizers.com/Fertilizers/Knowledge\%20Center/KCl_in_fertigation.pd $\mathrm{f}$

[22] Kumar S, Kanawjia SK. Influence of partial replacement of $\mathrm{NaCl}$ with $\mathrm{KCl}$ on sensory and textural characteristics of buffalo feta-type cheese during ripening. J Food Process Preserv 2011; 36(5):431-437.

[23] NREL. Determination of extractives in biomass. 2005. Golden, Colo.: National Renewable Energy Laboratory. Available at: www.nrel.gov/biomass/analytical_procedures.html.

[24] NREL. Determination of ash in biomass. 2005. Golden, Colo.: National Renewable Energy Laboratory. Available at: www.nrel.gov/biomass/analytical_procedures.html.

[25] NREL. Determination of structural carbohydrates and lignin in biomass. 2008. Golden, Colo.: National Renewable Energy Laboratory. Available at: www.nrel.gov/biomass/analytical_procedures.html.

[26] NREL. Determination of cellulase activity. 2008. Golden, Colo.: National Renewable Energy Laboratory. Available at: www.nrel.gov/biomass/analytical_procedures.html.

[27] Pessani NK, Atiyeh HK, Wilkins R, Beller DD, Banat IM. Simultaneous saccharification and fermentation of Kanlow switchgrass by thermotolerant Kluyveromyces marxianus IMB3: The effect of enzyme loading, temperature and higher solid loadings. Bioresour Technol 2011; 102(22):10618-10624.

[28] Gao Y, Xu J, Yuan Z, Zhang Y, Liu Y, Liang C. Fed batch enzymatic hydrolysis from alkali-pretreated sugarcane bagasse for high-concentration sugar production. 
[29] Zhang Y, Liu YY, Xu JL, Yuan ZH, Qi W, Zhuang X-S, et al. High solid and low enzyme loading based saccharification of agricultural biomass. BioResources 2012; 7(1): 345-353.

[30] Khoddami A, Wilkes MA, Roberts TH. Techniques for analysis of plant phenolic compounds. Molecules 2013; 18(2): 2328-2375.

[31] Peng X, Bian J, Li M, Xiao X, Xia X, Yin W, et al. Graded ethanol fractionation and structural characterization of alkali-extractable hemicelluloses from Olea europaea L. BioResources 2013; 8(1): 1110-1123.

[32] Kim TH, Lee YY. Pretreatment of corn stover by soaking in aqueous ammonia at moderate temperatures. Appl Biochem Biotechnol 2007, 137-140:81-92.

[33] Nghiem NP, Kim TH, Yoo CG, Hicks KB. Enzymatic fractionation of SAApretreated barley straw for production of fuel ethanol and astaxanthin as a valueadded co-product. Appl Biochem Biotechnol 2013; 171(2):341-51.

[34] Karki B, Maurer D, Box S, Kim TH, Jung S. Ethanol production from soybean fiber, a co-product of aqueous oil extraction, using a soaking in aqueous ammonia pretreatment. JAOCS 2012; 89(7): 1345-53.

[35] Kim TH, Taylor F, Hicks KB. Bioethanol production from barley hull using SAA (soaking in aqueous ammonia) pretreatment. Bioresour Technol 2008; 99(13): 56945702 .

[36] Jain A, Wei Y, Tietje A. Biochemical conversion of sugarcane bagasse into bioproducts. Biomass Bioenergy 2016; 93:227-242.

[37] Agarwal U, Zhu JY, Ralph SA. Enzymatic hydrolysis of biomass: Effects of crystallinity, particle size, and lignin removal. 16th ISWFPC. 2011: p. 910-914.

[38] Mansikkamäki P, Lahtinen M, Rissanen K. Structural changes of cellulose crystallites induced by mercerization in different solvent systems; determined by powder X-ray diffraction method. Cellulose 2005; 12(3):233-242.

[39] Albert A, Serjeant EP. The determination of ionization constants - a laboratory manual. 3rd ed. New York: Chapman and Hall; 1984.

[40] Goulet MT. The effect of pulping, bleaching, and refining operations on the electrokinetic properties of wood fiber fines [Dissertation]. Atlanta (GA): Lawrence University; 1989.

[41] Reijenga J, Hoof Av, Loon Av, Teunissen B. Development of methods for the determination of pKa value. Anal Chem Insights 2013; 8: 53-71.

[42] Jain A, Walker TH. Pretreatment composition for biomass conversion process. US patent application WO 2013151927 A1. Oct 10, 2013.

[43] Karlsson A, Agnemo R. High consistency hydrogen peroxide bleaching of mechanical pulps with varying amounts of fines. Nord Pulp Pap Res J 2010; 25(3):256-268.

[44] Suess HU, GmbH D, Janik M, GmbH AQ. On the decomposition of hydrogen peroxide via the peroxocarbonic acid anion. TAPPSA. http://www.tappsa.co.za/archive3/Journal_papers/decomposition_of_hydrogen_pero/d ecomposition_of_hydrogen_pero.html

[45] Mitchell MAG, Wynnes-Jones WFK. Thermodynamic and other properties of solutions involving hydrogen bonding. Discuss Faraday Soc 1953; 15:161-168.

[46] Ghahremani H, Moradi A, Abedini-Torghabeh J, Hassani SM. Measuring surface tension of binary mixtures of water+alcohols from the diffraction pattern of surface ripples. Chem Sin 2011; 2(6):212-221 
[47] Váquez G, Alvarez E, Navaza JM. Surface tension of alcohol + water. J Chem Eng Data 1995; 40(3): 611-614.

[48] Zhao X, Cheng K, Liu D. Organosolv pretreatment of lignocellulosic biomass for enzymatic hydrolysis. Appl Microbio Biotechnol 2009; 82(5):815-827.

[49] Helmy SA, Baky YEDA. Role of ethoxide ion in soda-ethanol pulping of Egyptian bagasse. J King Abdulaziz Univ, Sci 1996; 8:81-87.

[50] Watson BJ, Hammouda B, Briber RM, Hutcheson SW. Influence of organic liquids on the nanostructure of precipitated cellulose. J Appl Polym Sci 2013; 127(4):26202627.

[51] Wu N, Hubble MA, Rojas OJ, Park S. Permeation of polyelectrolytes and other solutes into the pore spaces of water-swollen cellulose: A review. BioResources 2009; 4(3): 1222-1262.

[52] Alon A, Staal PW. Methods for the preparation and recovery of alkali metal citrates. US Patent 5041645. Aug 20, 1991.

[53] Li J, Li S, Han B, Yu M, Li G, Jiang Y. A novel cost-effective technology to convert sucrose and homocelluloses in sweet sorghum stalks into ethanol. Biotechnol Biofuels 2013; 6(174):1-12.

[54] Fileti EE, Chaudhuri P, Canuto S. Relative strength of hydrogen bond interaction in alcohol-water complexes. Chem Phys Lett 2004; 400(4):494-499.

[55] Saizi L, Padroa A, Guaardia E. Dynamics and hydrogen bonding in liquid ethanol. Mol Phys 1999; 97(7):897-905.

[56] Seydibeyoğlu MÖ. A novel partially biobased PAN-lignin blend as a potential carbon fiber precursor. J Biomed Biotechnol 2012; Article ID 598324: 8 p.

[57] Philips RB, Jameel H, Chang HM. Integration of pulp and paper technology with bioethanol production. Biotechnol Biofuels 2013; 6(13): 12 p. 
Tables

Table 1 - Central composite design for EHOs treatment analysis.

A. Variables with their coded and uncoded values.

\begin{tabular}{|c|c|c|c|c|c|c|c|}
\hline & \multicolumn{5}{|c|}{ Coded } & \\
\hline & & $(-2)^{[\mathrm{a}]}$ & $(-1)$ & (0) & $(+1)$ & $(+2)$ & \\
\hline & Temperature $\left({ }^{\circ} \mathrm{C}\right)$ & $38^{[\mathrm{b}]}$ & 48 & 58 & 68 & 78 & \\
\hline 0 & Ethanol (\%) & 0 & 15 & 30 & 45 & 60 & \\
\hline ב्ञ & $\mathrm{KOH}\left(\mathrm{g} \mathrm{L}^{-1}\right)$ & 0 & 12.5 & 25 & 37.5 & 50 & \\
\hline & $\mathrm{H}_{2} \mathrm{O}_{2}\left(\mathrm{~g} \mathrm{~L}^{-1}\right)$ & 0 & 12.5 & 25 & 37.5 & 50 & \\
\hline
\end{tabular}

B. Experimental design and sample preparations based on the response surface methodology.

\begin{tabular}{|c|c|c|c|c|c|}
\hline \multirow{2}{*}{ P \# } & \multicolumn{5}{|c|}{ Variables } \\
\hline & Temperature & Ethanol & $\mathrm{KOH}$ & $\mathrm{H}_{2} \mathrm{O}_{2}$ & Water \\
\hline 1 & $(-2) 38$ & $(0)^{[\mathrm{a}]} 30^{[\mathrm{b}]}[\mathbf{2 4 . 0}]^{[\mathrm{c}]}$ & (0) $25.0[\mathbf{2 . 0}]$ & (0) $25.0[\mathbf{5 . 7 1}]$ & [48.29] \\
\hline 2 & $(-1) 48$ & (+1) 45 [36.0] & (+1) 37.5 [3.0] & (+1) 37.5 [8.57] & [32.43] \\
\hline 3 & $(-1) 48$ & (+1) $45[\mathbf{3 6 . 0}]$ & $37.5[\mathbf{3 . 0}]$ & (-1) $12.5[\mathbf{2 . 8 6}]$ & [38.14] \\
\hline 4 & $(-1) 48$ & (+1) 45 [36.0] & (-1) 12.5 [1.0] & (+1) 37.5 [8.57] & [34.43] \\
\hline 5 & $(-1) 48$ & (+1) 45 [36.0] & $(-1) 12.5[\mathbf{1 . 0}]$ & (-1) $12.5[\mathbf{2 . 8 6}]$ & {$[40.14]$} \\
\hline 6 & $(-1) 48$ & (-1) 15 [12.0] & (+1) $37.5[\mathbf{3 . 0}]$ & (+1) 37.5 [8.57] & [56.43] \\
\hline 7 & $(-1) 48$ & $(-1) 15$ [12.0] & (+1) $37.5[\mathbf{3 . 0}]$ & (-1) 12.5 [2.86] & {$[62.14]$} \\
\hline 8 & $(-1) 48$ & (-1) 15 [12.0] & (-1) 12.5 [1.0] & (+1) 37.5 [8.57] & {$[58.43]$} \\
\hline 9 & $(-1) 48$ & (-1) 15 [12.0] & (-1) 12.5 [1.0] & (-1) $12.5[\mathbf{2 . 8 6}]$ & [64.14] \\
\hline 10 & (0) 58 & (0) $30[\mathbf{2 4 . 0}]$ & (0) $25.0[\mathbf{2 . 0}]$ & (0) $25.0[\mathbf{5 . 7 1}]$ & [48.29] \\
\hline 11 & (0) 58 & (0) 30 [24.0] & (0) $25.0[\mathbf{2 . 0}]$ & (0) 25.0 [5.71] & [48.29] \\
\hline 12 & (0) 58 & (0) 30 [24.0] & (0) $25.0[\mathbf{2 . 0}]$ & (0) 25.0 [5.71] & [48.29] \\
\hline 13 & (0) 58 & (0) 30 [24.0] & (0) $25.0[\mathbf{2 . 0}]$ & (0) $25.0[\mathbf{5 . 7 1}]$ & [48.29] \\
\hline 14 & (0) 58 & $(-2) 0[\mathbf{0 . 0}]$ & (0) $25.0[\mathbf{2 . 0}]$ & (0) $25.0[\mathbf{5 . 7 1}]$ & [72.29] \\
\hline 15 & (0) 58 & (+2) $60[48.0]$ & (0) $25.0[\mathbf{2 . 0}]$ & (0) $25.0[\mathbf{5 . 7 1}]$ & [24.29] \\
\hline 16 & (0) 58 & (0) 30 [24.0] & (-2) $00.0[\mathbf{0 . 0}]$ & (0) 25.0 [5.71] & [50.29] \\
\hline 17 & (0) 58 & (0) 30 [24.0] & (+2) $50.0[4.0]$ & (0) $25.0[\mathbf{5 . 7 1}]$ & [46.29] \\
\hline 18 & (0) 58 & (0) 30 [24.0] & (0) 25.0 [2.0] & (-2) $00.0[\mathbf{0 . 0 0}]$ & {$[54.00]$} \\
\hline 19 & (0) 58 & (0) 30 [24.0] & (0) $25.0[\mathbf{2 . 0}]$ & $50.0[\mathbf{1 1 . 4 3}]$ & [42.57] \\
\hline 20 & (+1) 68 & (+1) $45[\mathbf{3 6 . 0}]$ & (+1) 37.5 [3.0] & $(+1) 37.5[8.57])$ & [32.43] \\
\hline 21 & (+1) 68 & (+1) 45 [36.0] & (+1) $37.5[\mathbf{3 . 0}])$ & (-1) 12.5 [2.86] & [38.14] \\
\hline 22 & (+1) 68 & (+1) 45 [36.0] & (-1) 12.5 [1.0] & (+1) 37.5 [8.57] & [34.43] \\
\hline 23 & (+1) 68 & (+1) $45[\mathbf{3 6 . 0}]$ & $(-1) 12.5[\mathbf{1 . 0}]$ & (-1) $12.5[\mathbf{2 . 8 6}]$ & {$[40.14]$} \\
\hline 24 & (+1) 68 & $(-1) 15$ [12.0] & (+1) 37.5 [3.0] & (+1) 37.5 [8.57] & [56.43] \\
\hline 25 & (+1) 68 & (-1) 15 [12.0] & $37.5[\mathbf{3 . 0}]$ & (-1) $12.5[\mathbf{2 . 8 6}]$ & {$[62.14]$} \\
\hline 26 & (+1) 68 & $(-1) 15$ [12.0] & (-1) 12.5 [1.0] & (+1) 37.5 [8.57] & {$[58.43]$} \\
\hline 27 & (+1) 68 & $(-1) 15$ [12.0] & $(-1) 12.5[\mathbf{1 . 0}]$ & (-1) 12.5 [2.86] & [64.14] \\
\hline 28 & (+2) 78 & (0) $30[\mathbf{2 4 . 0}]$ & (0) $25.0[\mathbf{2 . 0}]$ & (0) $25.0[\mathbf{5 . 7 1}]$ & [48.29] \\
\hline
\end{tabular}

Note:

[a] Values represent coded variables for the response surface methodology analysis.

${ }^{[b]}$ Values represent the uncoded variables used in the response surface analysis.

${ }^{[c]}$ Values represent the actual composition of ethanol $(\mathrm{mL}), \mathrm{KOH}(\mathrm{g}), \mathrm{H}_{2} \mathrm{O}_{2}(\mathrm{~mL})$, and added water $(\mathrm{mL})$ at the specific temperature ranges in the sample preparations for the response surface analysis. 
Table 2 - Effect of chemical treatments on GPWC.

A. Sample weight before and after treatments

\begin{tabular}{lccc}
\hline Chemical Treatments & Water & AHP $^{[\mathrm{a}]}$ & EHOs $^{[\mathrm{b}]}$ \\
\hline Before treatment $(\mathrm{g})$ & $8.07 \pm 0.02$ & $8.06 \pm 0.02$ & $8.07 \pm 0.03$ \\
After treatment $(\mathrm{g})$ & $7.93 \pm 0.01$ & $5.92 \pm 0.13$ & $6.21 \pm 0.20$ \\
\hline
\end{tabular}

B. Compositional analysis of GPWC under different treatment conditions

\begin{tabular}{|c|c|c|c|}
\hline \multirow{2}{*}{ Components } & \multicolumn{3}{|c|}{ Composition $\left(\mathrm{g}(100 \mathrm{~g} \text { dried GPWC })^{-1}\right)$} \\
\hline & Untreated & AHP & EHOs \\
\hline Cellulose & $46.38 \pm 0.73$ & $59.16 \pm 1.75$ & $61.31 \pm 1.04$ \\
\hline Glucan & $46.38 \pm 0.73$ & $59.16 \pm 1.75$ & $61.31 \pm 1.04$ \\
\hline Hemicellulose & $22.46 \pm 0.52$ & $18.30 \pm 0.35$ & $17.42 \pm 0.18$ \\
\hline Xylan & $7.51 \pm 0.44$ & $4.70 \pm 0.33$ & $4.45 \pm 0.41$ \\
\hline Arabinan & $0.77 \pm 0.05$ & $0.48 \pm 0.05$ & $0.39 \pm 0.06$ \\
\hline Galactan & $1.76 \pm 0.44$ & $0.42 \pm 0.03$ & $0.41 \pm 0.05$ \\
\hline Mannan & $12.40 \pm 0.30$ & $12.70 \pm 0.10$ & $12.19 \pm 0.23$ \\
\hline Lignin & $29.90 \pm 1.12$ & $22.01 \pm 1.42$ & $20.69 \pm 0.85$ \\
\hline $\mathrm{AIL}^{[\mathrm{c}]}$ & $29.37 \pm 1.14$ & $21.48 \pm 1.45$ & $20.08 \pm 0.87$ \\
\hline $\operatorname{ASL}^{[d]}$ & $0.53 \pm 0.01$ & $0.54 \pm 0.03$ & $0.61 \pm 0.02$ \\
\hline Ash & $0.47 \pm 0.04$ & $0.58 \pm 0.07$ & $0.59 \pm 0.04$ \\
\hline Extractive & $0.81 \pm 0.10$ & & \\
\hline Solid residue & $100.02 \pm 2.51$ & $100.04 \pm 3.59$ & $100.01 \pm 2.11$ \\
\hline
\end{tabular}

Note:

[a] $\mathrm{AHP}=$ Alkaline hydrogen peroxide,

${ }^{[b]}$ EHOs = Ethyl-hydro-oxides .

Chemical treatment conditions: solvent: sample ratio $1: 10(\mathrm{wt} / \mathrm{vol})$ at $78{ }^{\circ} \mathrm{C}$ for $24 \mathrm{~h}$.

Cellulose: Glucan

Hemicellulose: Xylan + Arabinan + Galactan + Mannan

Lignin: ${ }^{[c]}$ AIL (Acid insoluble lignin) $+{ }^{[d]}$ ASL (Acid-soluble lignin).

Values are expressed as mean and standard error with two observations made at each combination. 
Table 3 - Analysis of variance (ANOVA) for the quadratic model resulted from glucan conversion (\%) and total polysaccharide conversion (\%) of GPWC.

A. Based on glucan conversion (\%)

\begin{tabular}{llllll}
\hline Residual & DF & Sum of Squares & Mean Square & F Ratio & Pr $>$ F \\
\hline Model & 14 & 19304.83 & 1378.92 & 75.66 & $<.0001^{*}$ \\
Lack of Fit & 10 & 663.38 & 66.34 & 24.52 & $<.0001^{*}$ \\
Pure Error & 31 & 83.88 & 2.71 & & \\
Total Error & 41 & 747.26 & & $\mathrm{R}^{2}=0.9958$ & \\
\hline
\end{tabular}

B. Based on total polysaccharide conversion (\%)

\begin{tabular}{llllll}
\hline Residual & DF & Sum of Squares & Mean Square & F Ratio & Pr $>\mathrm{F}$ \\
\hline Model & 14 & 12191.42 & 870.82 & 76.93 & $<.0001^{*}$ \\
Lack of Fit & 10 & 403.66 & 40.37 & 20.71 & $<.0001^{*}$ \\
Pure Error & 31 & 60.41 & 1.95 & & \\
Total Error & 41 & 464.08 & & $\mathrm{R}^{2}=0.9952$ & \\
\hline
\end{tabular}


Figures

AHP-Treated GPWC
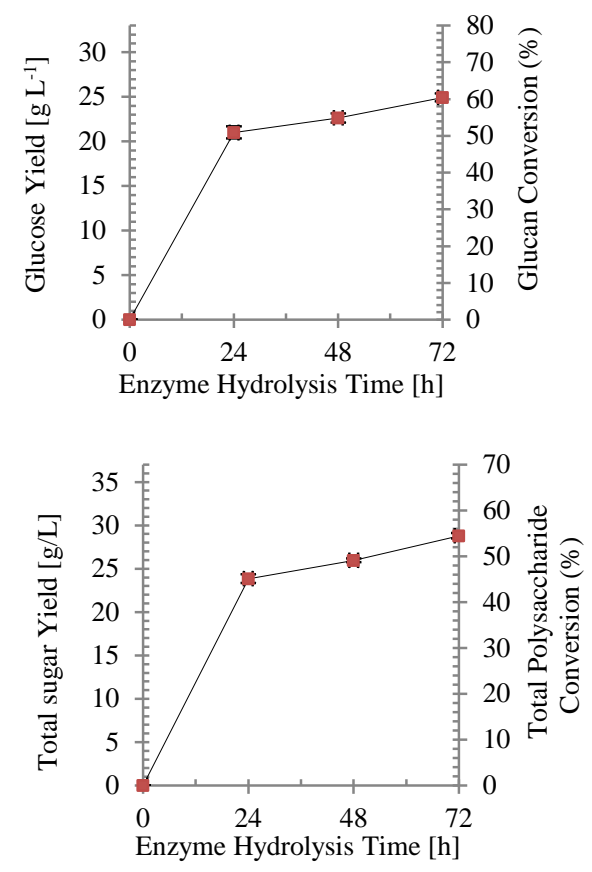

EHOs-Treated GPWC
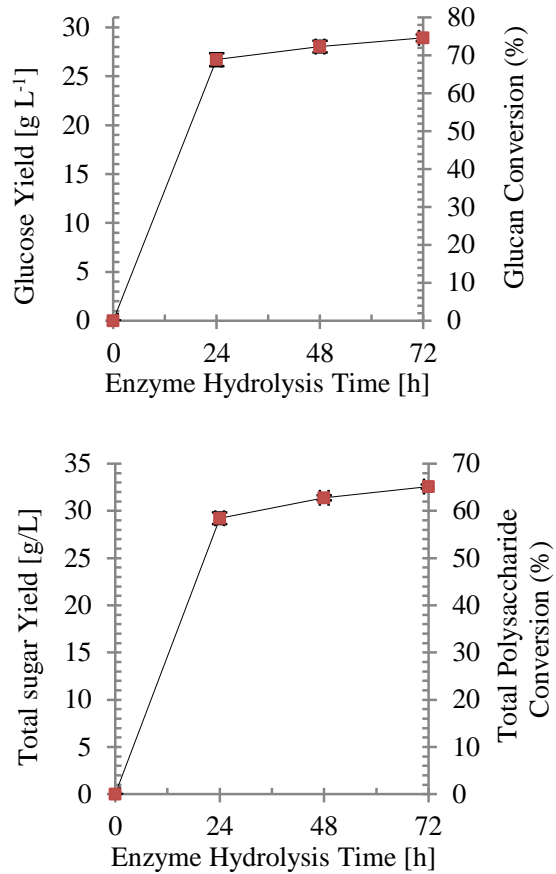

Fig. 1 - Enzyme hydrolysis of AHP-treated and EHOs-treated GPWC using Accellerase ${ }^{\circledR} 1500$ with the resulted sugar yields and their conversions. Note: Values are average of three replicates. Error bars represent standard errors. 
A. Based on glucan conversion (\%)

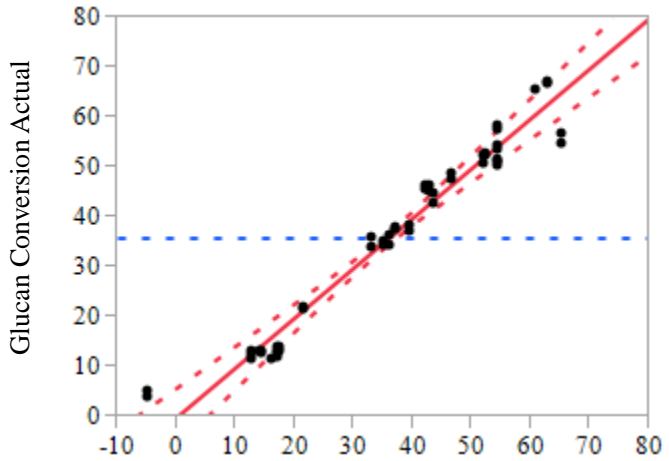

Glucan Conversion Predicted

$\mathrm{P}<.0001 \mathrm{RSq}=0.96 \mathrm{RMSE}=4.2692$

B. Based on total polysaccharide conversion (\%)

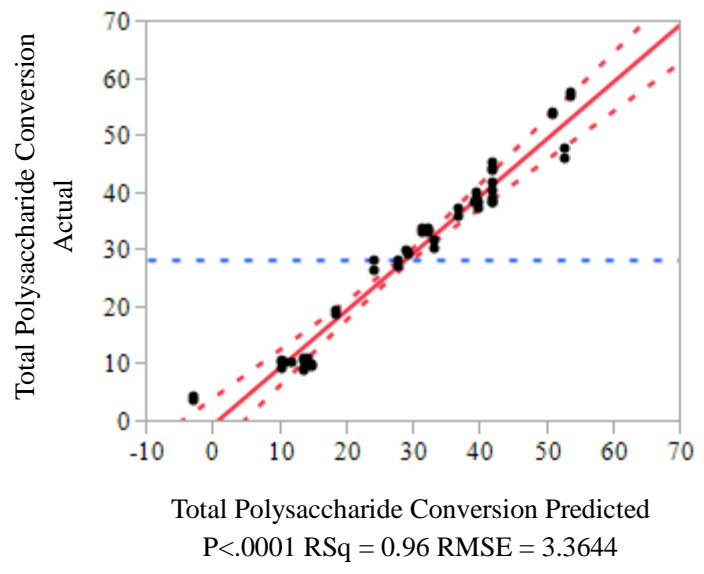

Fig. 2 - Analysis of enzymatic saccharification efficiencies of actual values vs. predicted values for glucan conversion (\%) and total polysaccharide conversion (\%) of GPWC using Accellerase ${ }^{\circledR} 1500$. 
A. Based on glucan conversion (\%)

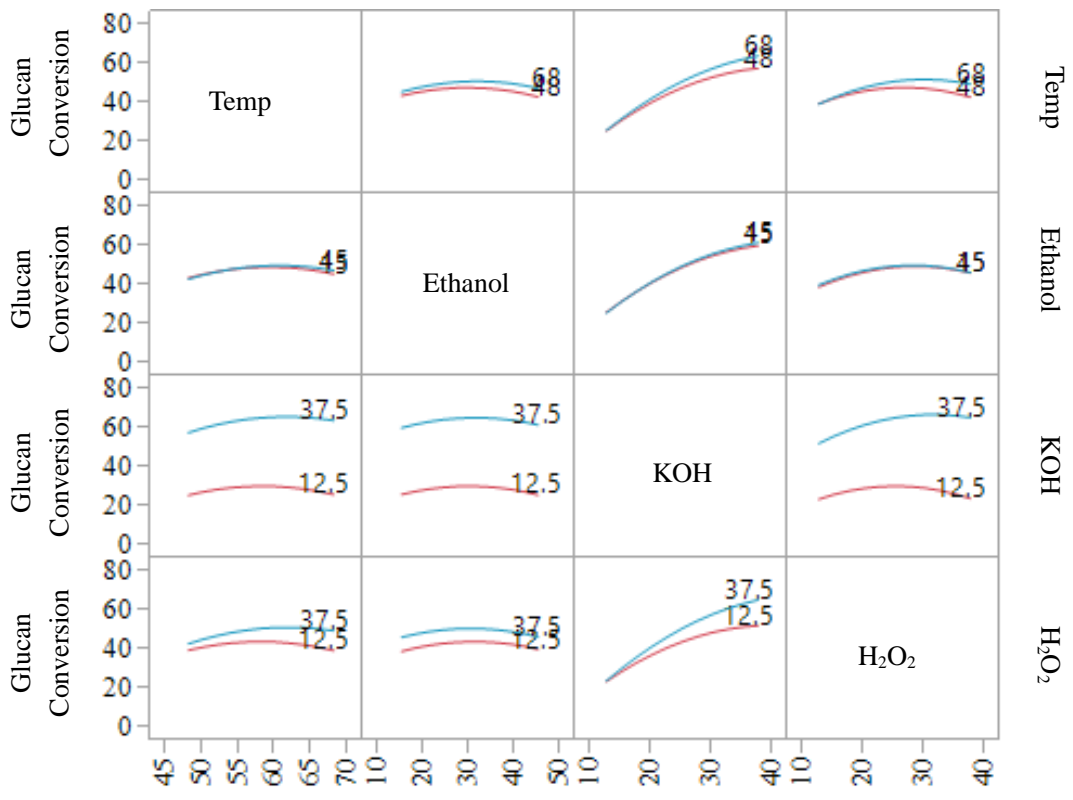

B. Based on total polysaccharide conversion (\%)

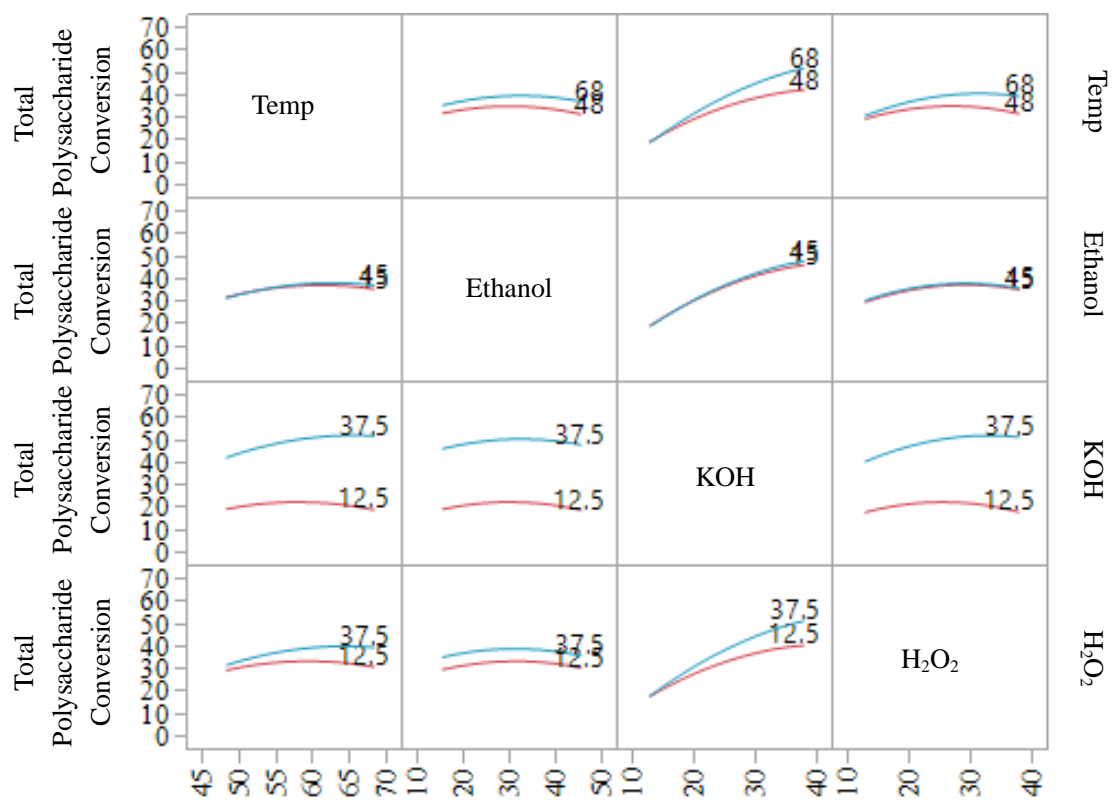

Fig. 3 - Interaction profiles for glucan conversion (\%) and total polysaccharide conversion (\%) as functions of temperature $\left(48,68^{\circ} \mathrm{C}\right)$, ethanol $(15,45 \%), \mathrm{KOH}\left(12.5,37.5 \mathrm{~g} \mathrm{~L}^{-1}\right)$ and $\mathrm{H}_{2} \mathrm{O}_{2}\left(12.5,37.5 \mathrm{~g} \mathrm{~L}^{-1}\right)$ during the enzymatic saccharification of GPWC using Accellerase ${ }^{\circledR} 1500$. 

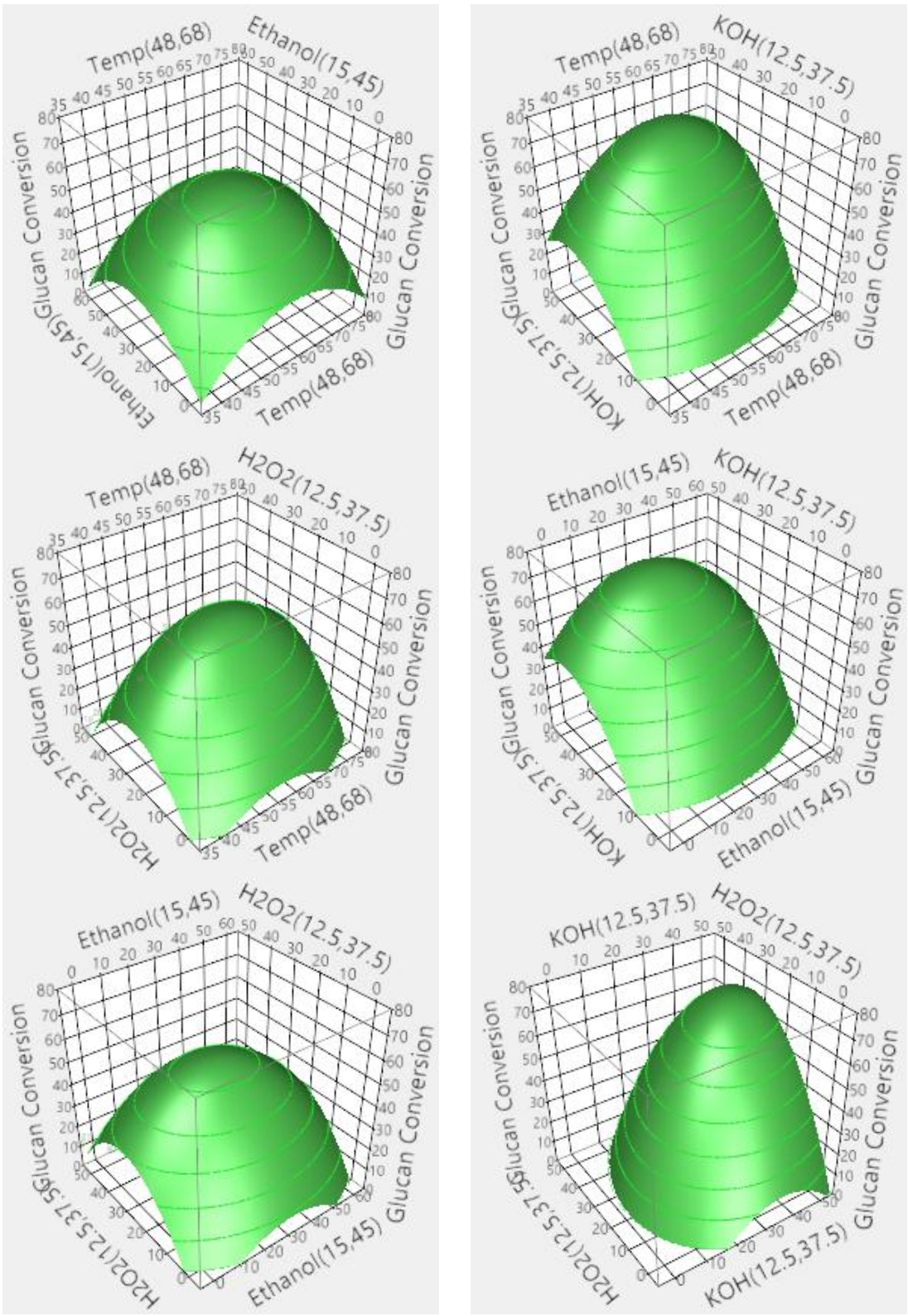

Fig. 4a - Surface profilers for glucan conversion (\%) as functions of temperature (at $58{ }^{\circ} \mathrm{C}$ ), ethanol (at $30 \%$ ), $\mathrm{KOH}\left(\right.$ at $\left.25 \mathrm{~g} \mathrm{~L}^{-1}\right)$ and $\mathrm{H}_{2} \mathrm{O}_{2}$ (at $\left.25 \mathrm{~g} \mathrm{~L}^{-1}\right)$ during the enzymatic saccharification of GPWC using Accellerase ${ }^{\circledR}$ 1500 . 


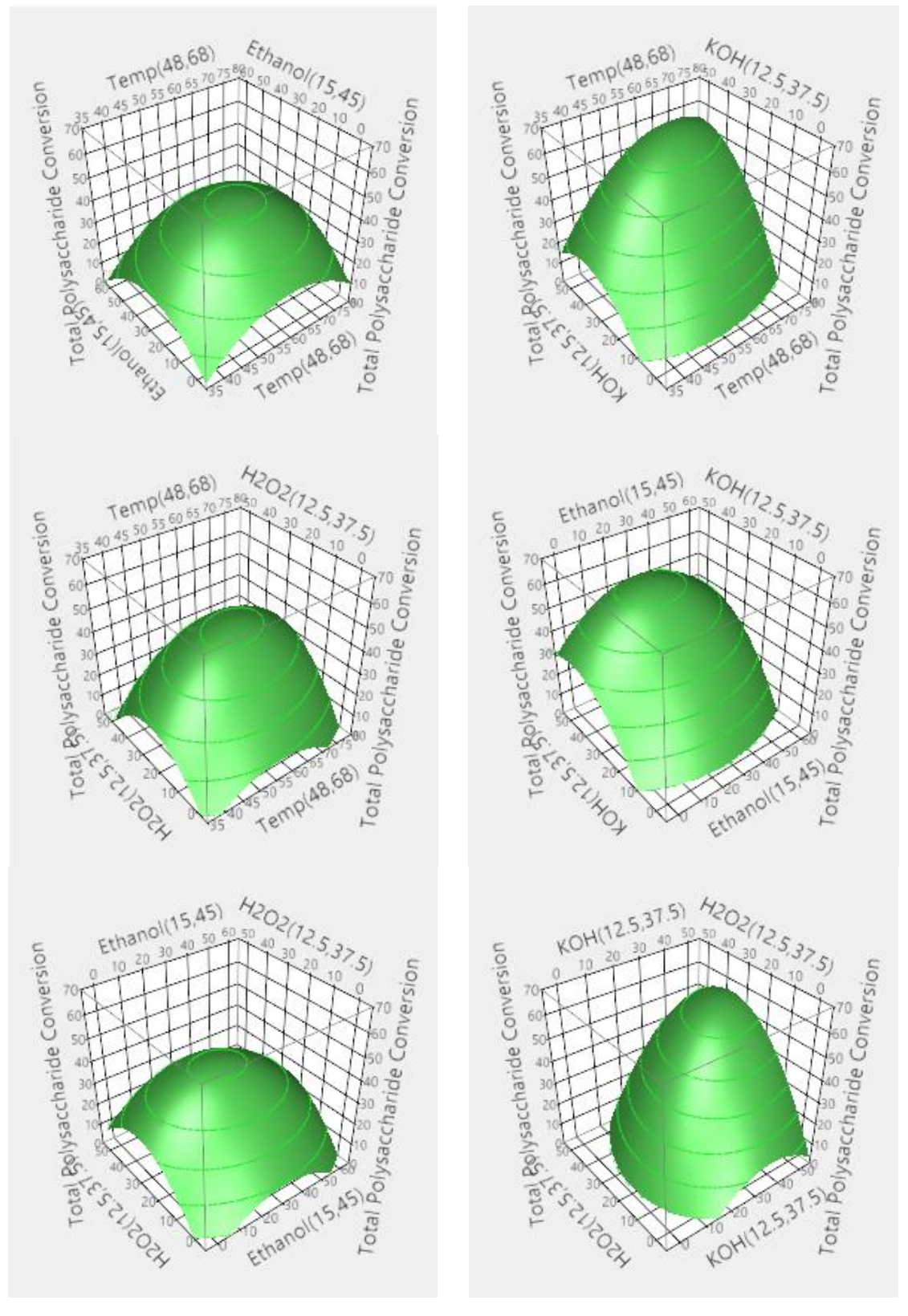

Fig. 4b - Surface profilers for total polysaccharide conversion $(\%)$ as functions of temperature $\left(\right.$ at $\left.58{ }^{\circ} \mathrm{C}\right)$, ethanol (at 30\%), $\mathrm{KOH}$ (at $25 \mathrm{~g} \mathrm{~L}^{-1}$ ) and $\mathrm{H}_{2} \mathrm{O}_{2}$ (at $25 \mathrm{~g} \mathrm{~L}^{-1}$ ) during the enzymatic saccharification of GPWC using Accellerase ${ }^{\circledR} 1500$. 
A. Based on glucan conversion (\%)

\begin{tabular}{|c|c|c|c|c|c|}
\hline Term & Estimate & Std Error & t Ratio & Profile & Prob $>|t|$ \\
\hline $\mathrm{KOH}\left(12.5,37.5 \mathrm{~g} \mathrm{~L}^{-1}\right)$ & 17.50 & 0.62 & 28.41 & & $<.0001^{*}$ \\
\hline $\mathrm{H}_{2} \mathrm{O}_{2} \times \mathrm{H}_{2} \mathrm{O}_{2}$ & -6.55 & 0.62 & -10.63 & & $<.0001^{*}$ \\
\hline $\mathrm{KOH} \times \mathrm{KOH}$ & -6.06 & 0.62 & -9.83 & & $<.0001^{*}$ \\
\hline Temp x Temp & -4.50 & 0.62 & -7.30 & & $<.0001^{*}$ \\
\hline $\mathrm{EtOH} \times \mathrm{EtOH}$ & -4.43 & 0.62 & -7.19 & & $<.0001^{*}$ \\
\hline $\mathrm{H}_{2} \mathrm{O}_{2}\left(12.5,37.5 \mathrm{~g} \mathrm{~L}^{-1}\right)$ & 3.37 & 0.62 & 5.47 & tis & $<.0001^{*}$ \\
\hline $\mathrm{KOH} \times \mathrm{H}_{2} \mathrm{O}_{2}$ & 3.21 & 0.75 & 4.26 & 布: & $0.0001 *$ \\
\hline $\operatorname{Temp}\left(48^{\circ}, 68^{\circ} \mathrm{C}\right)$ & 1.62 & 0.62 & 2.63 & & $0.0121^{*}$ \\
\hline Temp x $\mathrm{H}_{2} \mathrm{O}_{2}$ & 1.72 & 0.75 & 2.28 & 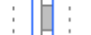 & $0.0278^{*}$ \\
\hline Temp x KOH & 1.49 & 0.75 & 1.98 & 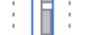 & 0.0546 \\
\hline Temp x EtOH & 0.60 & 0.75 & 0.80 & & 0.4290 \\
\hline EtOH x KOH & 0.42 & 0.75 & 0.56 & & 0.5778 \\
\hline $\operatorname{EtOH}(15,45 \%)$ & 0.30 & 0.62 & 0.49 & & 0.6282 \\
\hline $\mathrm{EtOH} \times \mathrm{H}_{2} \mathrm{O}_{2}$ & -0.22 & 0.75 & -0.29 & | & 0.7750 \\
\hline
\end{tabular}

B. Based on total polysaccharide conversion (\%)

\begin{tabular}{|c|c|c|c|c|c|}
\hline Term & Estimate & Std Error & $\mathrm{t}$ Ratio & Profile & Prob $>|t|$ \\
\hline $\mathrm{KOH}\left(12.5,37.5 \mathrm{~g} \mathrm{~L}^{-1}\right)$ & 13.96 & 0.49 & 28.75 & & $<.0001^{*}$ \\
\hline $\mathrm{H}_{2} \mathrm{O}_{2} \times \mathrm{H}_{2} \mathrm{O}_{2}$ & -4.48 & 0.49 & -9.23 & & $<.0001^{*}$ \\
\hline $\mathrm{KOH} \times \mathrm{KOH}$ & -4.20 & 0.49 & -8.66 & & $<.0001^{*}$ \\
\hline $\mathrm{EtOH} \times \mathrm{EtOH}$ & -3.36 & 0.49 & -6.91 & & $<.0001^{*}$ \\
\hline Temp x Temp & -3.28 & 0.49 & -6.76 & & $<.0001^{*}$ \\
\hline $\mathrm{H}_{2} \mathrm{O}_{2}\left(12.5,37.5 \mathrm{~g} \mathrm{~L}^{-1}\right)$ & 2.74 & 0.49 & 5.65 & & $<.0001^{*}$ \\
\hline $\operatorname{Temp}\left(48^{\circ}, 68^{\circ} \mathrm{C}\right)$ & 2.30 & 0.49 & 4.75 & & $<.0001^{*}$ \\
\hline $\mathrm{KOH} \times \mathrm{H}_{2} \mathrm{O}_{2}$ & 2.69 & 0.59 & 4.52 & 节: & $<.0001^{*}$ \\
\hline Temp x KOH & 2.51 & 0.59 & 4.22 & 办: & $0.0001^{*}$ \\
\hline Temp x $\mathrm{H}_{2} \mathrm{O}_{2}$ & 1.61 & 0.59 & 2.71 & t & $0.0098 *$ \\
\hline $\mathrm{EtOH} \times \mathrm{KOH}$ & 0.53 & 0.59 & 0.89 & & 0.3794 \\
\hline Temp x EtOH & 0.52 & 0.59 & 0.87 & & 0.3913 \\
\hline EtOH $(15,45 \%)$ & 0.34 & 0.49 & 0.70 & & 0.4902 \\
\hline $\mathrm{EtOH} \times \mathrm{H}_{2} \mathrm{O}_{2}$ & -0.05 & 0.59 & -0.08 & & 0.9338 \\
\hline
\end{tabular}

Fig. 5 - Sorted estimate parameters for glucan conversion (\%) and total polysaccharide conversion (\%) resulted through the interactions of temperature (Temp), ethanol (EtOH), $\mathrm{KOH}$, and $\mathrm{H}_{2} \mathrm{O}_{2}$ during the enzymatic saccharification of GPWC. Note: A bar chart shows t-ratio with the lines at 0.05 significance level. 
A. Based on glucan conversion (\%)

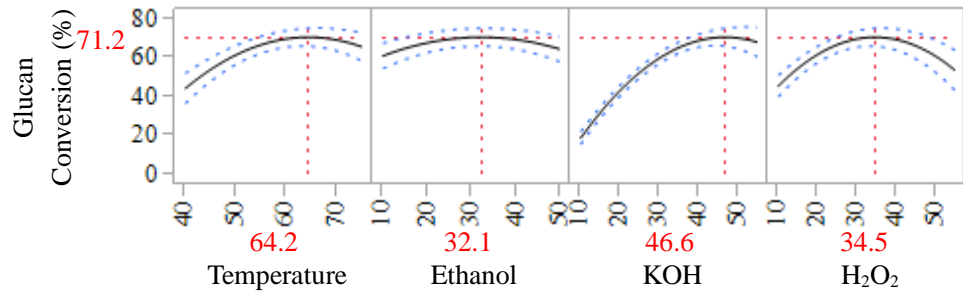

B. Based on total polysaccharide conversion (\%)

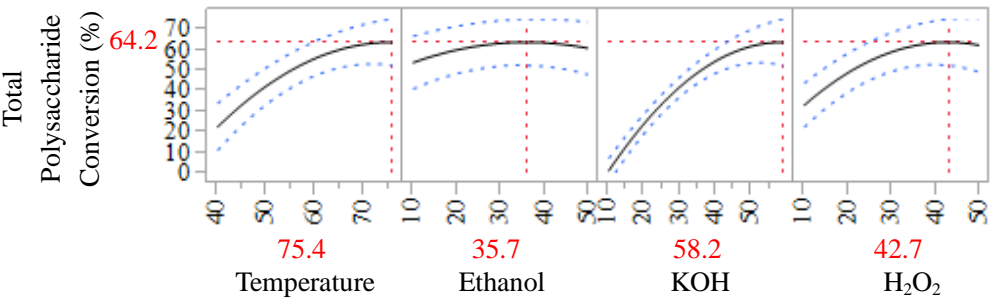

Fig. 6 - Optimized EHOs treatment conditions resulted through the enzymatic saccharification of GPWC using Accellerase $^{\circledR} 1500$. 

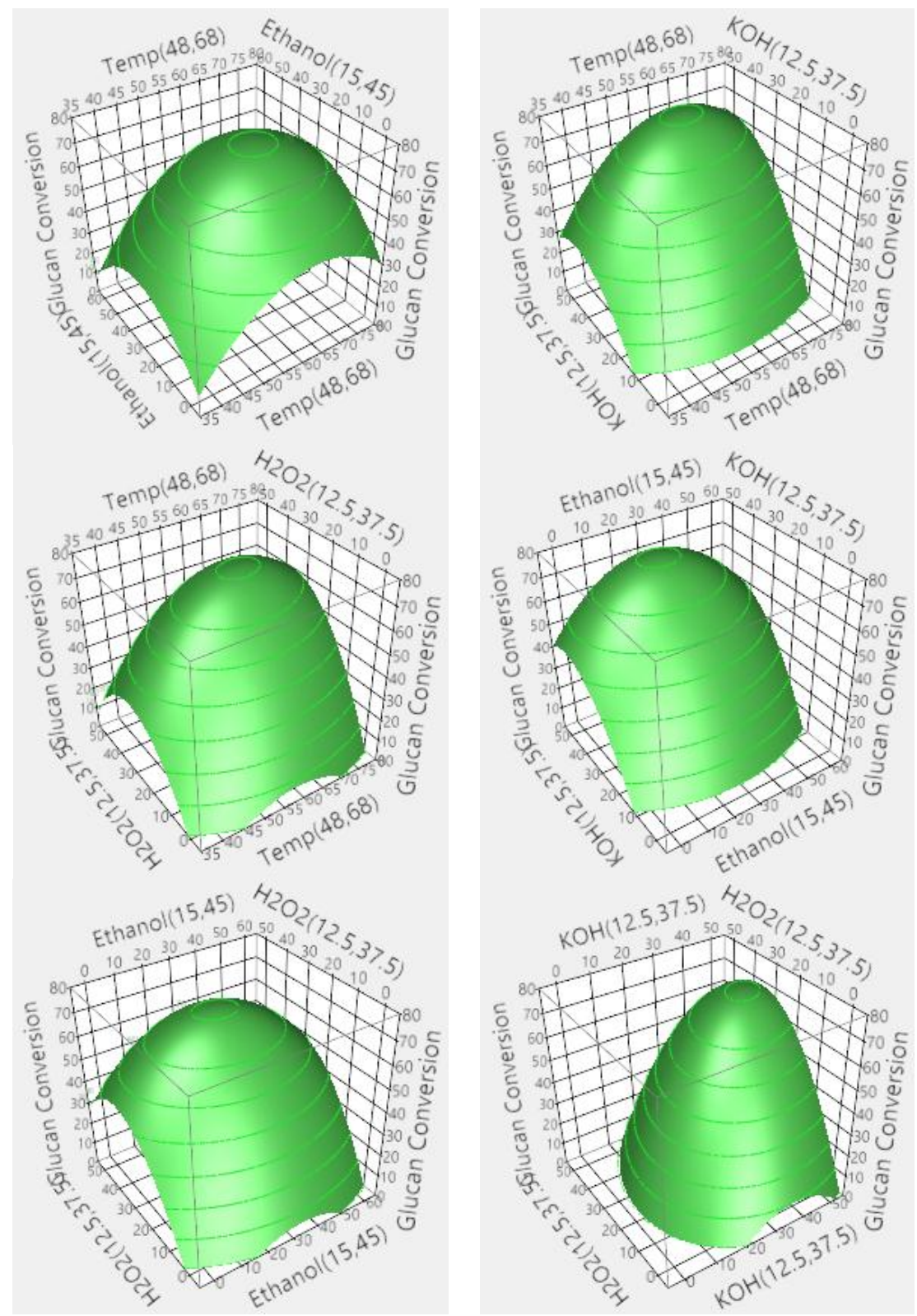

Fig. 7a-Optimized surface profilers for glucan conversion (\%) as functions of temperature (at $64.2{ }^{\circ} \mathrm{C}$ ), ethanol (at 32.1\%), $\mathrm{KOH}\left(\right.$ at $46.6 \mathrm{~g} \mathrm{~L}^{-1}$ ) and $\mathrm{H}_{2} \mathrm{O}_{2}$ (at $34.5 \mathrm{~g} \mathrm{~L}^{-1}$ ) during the enzymatic saccharification of GPWC using Accellerase ${ }^{\circledR} 1500$. 

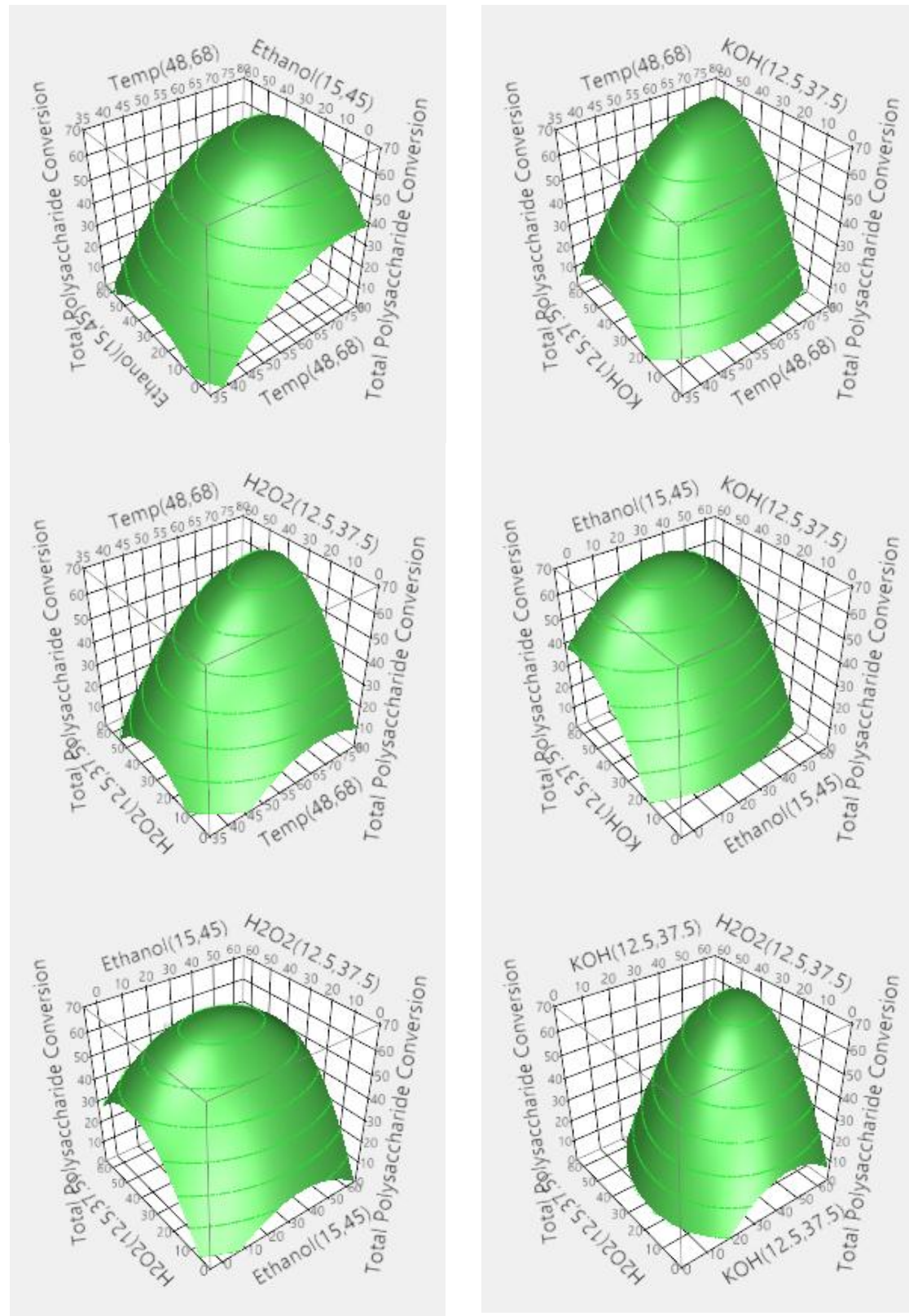

Fig. 7b - Optimized surface profilers for total polysaccharide conversion (\%) as functions of temperature (at $75.4{ }^{\circ} \mathrm{C}$ ), ethanol (at $35.7 \%$ ), $\mathrm{KOH}$ (at $58.2 \mathrm{~g} \mathrm{~L}^{-1}$ ) and $\mathrm{H}_{2} \mathrm{O}_{2}$ (at $42.7 \mathrm{~g} \mathrm{~L}^{-1}$ ) during the enzymatic saccharification of GPWC using Accellerase ${ }^{\circledR} 1500$. 
$\underline{\text { Appendix-A }}$

Table A1 - Central composite design: Chemical composition and enzymatic saccharification of GPWC.

\begin{tabular}{|c|c|c|c|c|c|c|c|}
\hline \multirow{2}{*}{$\begin{array}{l}\mathrm{P} \\
\#\end{array}$} & \multirow{2}{*}{$\begin{array}{c}\text { Biomass } \\
\text { recovery } \\
\text { after } \\
\text { treatment }{ }^{[1]} \\
(\%)\end{array}$} & \multirow{2}{*}{$\begin{array}{l}\text { Moisture } \\
\text { content } \\
\quad(\mathrm{g})\end{array}$} & \multicolumn{2}{|c|}{$\begin{array}{l}\text { Chemical Composition }{ }^{[1]} \\
\left.\mathrm{g}(100 \mathrm{~g} \text { dried } \mathrm{GPWC})^{-1}\right)\end{array}$} & \multicolumn{3}{|c|}{$\begin{array}{c}\text { Enzyme Hydrolysis }{ }^{[2]} \\
(\%)\end{array}$} \\
\hline & & & G & XMG & GC & XMGC & TPC \\
\hline 1 & $86.2(0.5)$ & $19.7(0.6)$ & $48.0(0.4)$ & $21.4(0.3)$ & $35.0(1.0)$ & $10.4(0.3)$ & $27.5(0.8)$ \\
\hline 2 & $82.5(0.3)$ & $16.8(0.7)$ & $49.2(0.7)$ & $24.5(0.5)$ & $51.5(0.8)$ & $11.0(0.1)$ & $38.0(0.6)$ \\
\hline 3 & $82.7(0.2)$ & $17.7(0.2)$ & $48.2(0.6)$ & $23.6(0.8)$ & $45.7(0.7)$ & $9.1(0.2)$ & $33.7(0.4)$ \\
\hline 4 & $86.2(0.2)$ & $17.9(0.3)$ & $46.0(0.2)$ & $24.9(0.6)$ & $11.9(0.4)$ & $4.9(0.6)$ & $9.4(0.0)$ \\
\hline 5 & $86.7(0.1)$ & $17.9(0.5)$ & $46.4(0.5)$ & $24.2(0.6)$ & $11.5(0.0)$ & $5.0(0.3)$ & $9.2(0.1)$ \\
\hline 6 & $81.2(0.2)$ & $16.5(0.5)$ & $47.9(0.5)$ & $24.5(0.6)$ & $52.7(0.2)$ & $10.7(0.1)$ & $38.5(0.1)$ \\
\hline 7 & $80.9(0.1)$ & $16.2(0.9)$ & $48.3(0.8)$ & $24.3(1.0)$ & $45.9(0.4)$ & $9.0(0.1)$ & $33.6(0.2)$ \\
\hline 8 & $86.6(0.1)$ & $20.0(1.0)$ & $45.6(0.7)$ & $24.6(0.9)$ & $13.1(0.3)$ & $5.5(0.4)$ & $10.4(0.1)$ \\
\hline 9 & $87.3(0.4)$ & $19.3(0.9)$ & $44.8(0.3)$ & $25.2(0.7)$ & $12.5(0.5)$ & $5.8(0.2)$ & $10.0(0.2)$ \\
\hline 10 & $80.4(0.1)$ & $15.9(0.3)$ & $57.9(0.2)$ & $23.5(0.7)$ & $52.4(1.3)$ & $8.5(0.2)$ & $39.7(1.0)$ \\
\hline 11 & $80.8(0.2)$ & $18.4(0.6)$ & $57.2(0.2)$ & $23.1(0.4)$ & $51.0(0.7)$ & $8.8(0.1)$ & $38.9(0.5)$ \\
\hline 12 & $80.3(0.4)$ & $18.3(0.7)$ & $56.7(1.0)$ & 21.7 (1.5) & $55.8(1.5)$ & $9.5(0.2)$ & $43.0(1.0)$ \\
\hline 13 & $80.3(0.3)$ & $18.3(0.6)$ & $57.8(0.5)$ & $22.9(0.2)$ & $57.9(0.4)$ & $11.7(0.8)$ & $44.8(0.5)$ \\
\hline 14 & $81.0(0.7)$ & $15.4(0.4)$ & $55.2(0.3)$ & $22.4(0.3)$ & $35.5(1.0)$ & $9.2(0.8)$ & $27.9(0.5)$ \\
\hline 15 & $80.6(0.3)$ & $15.2(0.6)$ & $57.1(0.2)$ & $23.4(1.2)$ & $37.9(0.3)$ & $10.8(0.4)$ & $30.0(0.1)$ \\
\hline 16 & $91.2(0.3)$ & $18.8(0.2)$ & $50.2(0.5)$ & $19.3(0.5)$ & $4.6(0.5)$ & $2.9(0.3)$ & $4.1(0.3)$ \\
\hline 17 & $77.5(0.4)$ & $14.1(0.3)$ & $58.1(0.6)$ & $17.8(0.3)$ & $55.8(1.0)$ & $18.5(0.5)$ & $47.0(0.9)$ \\
\hline 18 & $84.0(0.1)$ & $17.2(0.7)$ & $54.8(0.6)$ & $18.2(0.4)$ & $21.7(0.2)$ & $12.4(0.7)$ & $19.4(0.3)$ \\
\hline 19 & $81.5(0.2)$ & $16.4(1.0)$ & $54.5(1.4)$ & $18.3(0.4)$ & $34.8(0.2)$ & $14.0(0.2)$ & $29.6(0.2)$ \\
\hline 20 & $75.1(1.2)$ & $16.9(0.8)$ & $58.9(1.5)$ & $16.8(0.1)$ & $67.1(0.2)$ & $23.4(0.2)$ & $57.4(0.2)$ \\
\hline 21 & $73.6(0.2)$ & $14.6(0.2)$ & $62.3(0.3)$ & $20.3(0.9)$ & $48.2(0.5)$ & $14.1(0.8)$ & $39.8(0.6)$ \\
\hline 22 & $85.7(0.4)$ & $18.5(0.2)$ & $53.4(0.6)$ & $23.5(0.8)$ & $13.7(0.4)$ & $4.2(0.2)$ & $10.8(0.3)$ \\
\hline 23 & $85.1(0.4)$ & $19.2(0.5)$ & $52.8(0.4)$ & $20.9(0.3)$ & $13.1(0.1)$ & $4.0(0.3)$ & $10.6(0.0)$ \\
\hline 24 & $74.9(0.7)$ & $16.1(0.4)$ & $60.0(0.9)$ & $18.5(1.4)$ & $65.4(0.1)$ & $17.2(1.0)$ & $54.1(0.3)$ \\
\hline 25 & $73.3(0.7)$ & $16.1(0.6)$ & $62.4(0.6)$ & $18.9(1.2)$ & $43.8(0.9)$ & $13.0(0.1)$ & $36.6(0.7)$ \\
\hline 26 & $86.1(0.1)$ & $18.7(0.1)$ & $51.5(0.2)$ & $22.4(1.7)$ & $13.5(0.5)$ & $5.7(0.5)$ & $11.1(0.2)$ \\
\hline 27 & $86.0(0.2)$ & $21.0(0.7)$ & $51.2(0.5)$ & $25.0(0.4)$ & $13.4(0.0)$ & $5.3(0.3)$ & $10.7(0.1)$ \\
\hline 28 & $75.8(0.3)$ & $15.8(0.4)$ & $56.0(0.6)$ & $22.3(0.4)$ & $37.8(0.5)$ & $14.1(0.9)$ & $31.1(0.6)$ \\
\hline
\end{tabular}

Abbreviations:

$\mathrm{G}=$ Extractable glucan content $\mathrm{XMG}=$ Extractable xylan-mannan-galactan content.

$\mathrm{GC}=$ Glucan conversion $; \mathrm{XMGC}=$ Xylan-mannan-galactan conversion; $\mathrm{TPC}=$ Total polysaccharide conversion.

Note:

$\mathrm{P} \#$ represented the sequential orders of the treatment (see Table 1)

${ }^{[1]}$ Three and ${ }^{[2]}$ two observations were made at each combination.

Values represented the average with the bracketed standard error. 


\section{Appendix-B}

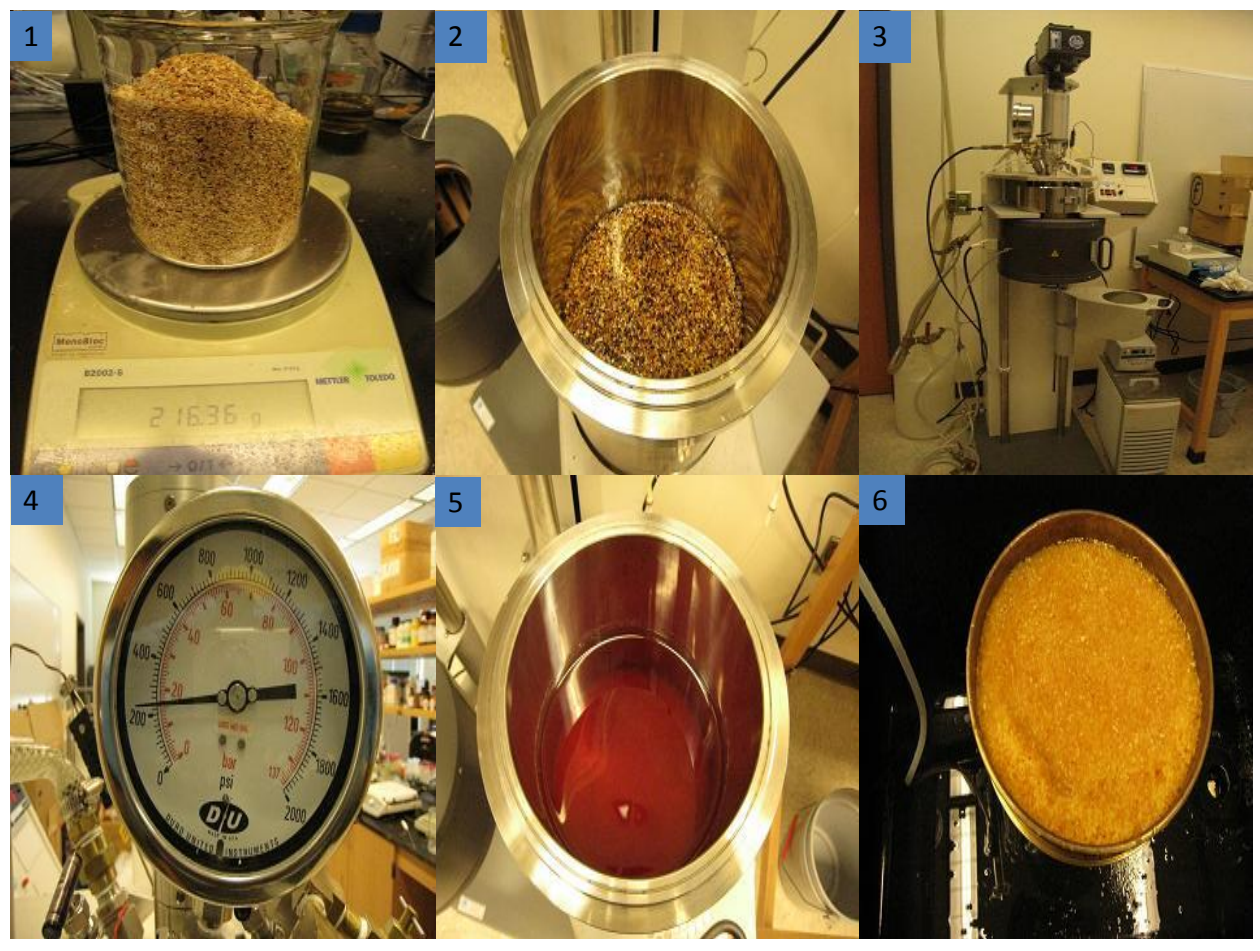

Fig. B1 - Experimental set up for EHOs treatment with GPWC using Parr reactor (Total volume $=3.8 \mathrm{~L}$, working volume $=$ approximately $2.2 \mathrm{~L}$ ).

Note:

1. Weighing of GPWC before treatment.

2. A mixture of ethanol-water-KOH solution with GPWC.

3. An enclosed Parr reactor vessel before addition of $\mathrm{H}_{2} \mathrm{O}_{2}$ to the vessel.

4. The final pressure after 5 minutes of $\mathrm{H}_{2} \mathrm{O}_{2}$ addition.

5. EHOs-treated GPWC in the solvent.

6. EHOs-treated GPWC after washing. 